\title{
Öğretmen Adaylarının Okuma Motivasyonları ve Sosyal Medyaya Özgü Epistemolojik İnançları Arasındaki İlişkinin İncelenmesi
}

\section{Investigation of the Relationship between Pre-service Teachers' Reading Motivations and Social Media-Specific Epistemological Beliefs*}

\author{
Hulusi Geçgel $^{* *}$ Fatih Kana $^{* * *}$ Nazife Esra Öztürk**** İlknur Yalçın Akkaş*****
}

Geliş / Received: 25.05.2020

Kabul / Accepted: 27.07.2020

\begin{abstract}
The aim of this study is to determine the relationship between reading motivation levels of Pre-Service Turkish teacher and their epistemological beliefs specific to social media. Relational screening model, which is one of the quantitative research models, was used in the research. The sample of the study studying at a state university located in the west of Turkey is located 209 Pre-Service Turkish teacher. In the research, "Social Media-Specific Epistemological Beliefs Scale" (valideated by Çelik (2019)) and "Adult Reading Motivation Scale" that was validated and validated by Yıldız, Yıldırım, Ateş, and Çetinkaya (2013) were used. The data were analyzed through descriptive statistical analysis, $t$ test, one way variance analysis (ANOVA), correlation analysis. It is observed that the pre-service teachers who participated in the study have read books in order to gain knowledge and relieve their curiosity, to have a pleasant time, to change their perspective and to enrich their vocabulary. It is seen that there is a positive and significant relationship between pre-service teachers' reading motivations and epistemological beliefs about social media.
\end{abstract}

Keywords: reading motivation, social media, epistemological belief.

ÖZ: Bu araştırmanın amacı, Türkçe öğretmeni adaylarının okuma motivasyonu düzeyleri ve sosyal medyaya özgü epistemolojik inançları arasındaki ilişkiyi tespit etmektir. Araştırmada nicel araştırma modellerinden ilişkisel tarama modeli kullanılmıştır. Araştırmanın örneklem grubunda Türkiye'nin batısında yer alan bir devlet üniversitesinde öğrenim gören 209 Türkçe öğretmeni adayı yer almaktadır. Araştırmada Çelik (2019) tarafından geçerliği ve güvenirliği yapılmış Sosyal Medyaya Özgü Epistemolojik İnançlar Ölçeği ve Yıldız, Yıldırım, Ateş ve Çetinkaya (2013) tarafından geçerliği ve güvenirliği yapılmış Yetişkin Okuma Motivasyonu Ölçeği kullanılmıştır. Veriler, betimsel istatistik analizleri, t-testi, tek yönlü varyans analizi (ANOVA), korelasyon analizi yoluyla analiz edilmiştir. Araştırmaya katılan öğretmen adaylarının genel olarak bilgi sahibi olmak ve merak duygusunu gidermek, keyifli zaman geçirmek, bakış açısını değiştirmek, söz varlığını zenginleştirmek için kitap okudukları görülmektedir. Öğretmen adaylarının okuma motivasyonlarıyla sosyal medyaya ilişkin epistemolojik inançları arasında genel olarak pozitif ve anlamlı bir ilişkinin bulunduğu görülmektedir.

Anahtar Kelimeler: okuma motivasyonu, sosyal medya, epistemolojik inanç

\footnotetext{
* Çanakkale Sosyal Bilimler ve Eğitim Bilimleri Etik Kurulu, 16.04.2020, 03 nolu toplantı, başvuru protokol numarası: 2020/35

** Dr. Öğretim Üyesi, ORCID ID: https://orcid.org/0000-0002-9277-6417, Çanakkale Onsekiz Mart Üniversitesi, Türkçe ve Sosyal Bilimler Eğitimi Bölümü, hgecgel@comu.edu.tr

*** Dr. Öğretim Üyesi, ORCID ID: https://orcid.org/0000-0002-1087-4081, Çanakkale Onsekiz Mart Üniversitesi, Türkçe ve Sosyal Bilimler Eğitimi Bölümü, fatihkana@hotmail.com

**** Yüksek Lisans Öğrencisi, ORCID ID: https://orcid.org/0000-0001-8505-7118, Çanakkale Onsekiz Mart Üniversitesi, Türkçe Eğitimi Bilim Dalı. esraa9671@gmail.com

***** Türkçe Öğretmeni, ORCID ID: https://orcid.org/0000-0001-8497-9161, Millî Eğitim Bakanlığ1, ilknurakkas17@gmail.com
}

Copyright (C) 2020 by JLERE (https://dergipark.org.tr/tr/pub/jlere)

ISSN: 2149-5602 


\section{Giriş}

Günümüzde bilgi ve bilgiye ulaşma araçlarının çeşitliliği her geçen gün artmaktadır. Bireyler için sadece okulda öğretilen bilgiler yeterli olmamakta (Şahin, 2019), çeşitli koşullar, pandemiler vb. nedeniyle okullar bile binaların dışına taşmış, eğitim ve öğretim evlerimizde uzaktan eğitimle gerçekleşir duruma gelmiştir. İnternet, sosyal medya, televizyon, telefon vb. birer eğitim aracı haline gelmiştir. Bu öğrenme araçları okuma motivasyonumuzu etkilemektedir.

Bilgiyi edinmede ve bilginin güvenilirliğini araştırmada en önemli yollardan biri okumadır. Bu özelliğiyle okuma, tüm öğrenmeler için kullanılması gereken bir beceridir. Okuma, basit bir süreç olmayıp gözün ve ses organlarının hareketleriyle başlayıp anlamaya kadar uzanan karmaşık bir süreçtir (Aktaş \& Bayram, 2018). Gündüz ve Şimşek (2011: 13) okumayı kişiliğin gelişmesine, bireysel ve toplumsal yaşamın zenginleşmesine katk1 sağlaması yönüyle ele almaktadır. Güneş (2009) okumayı, okuduğu yazının anlamını araştırdıktan sonra kendi zihninde yorumlayıp yapılandırmak olarak tanımlamaktadır. Okuduğu metne katkılar yapan, metni anlamlandıran ve metinden yeni anlamlar çıkaran ise okurdur.

Bireylerin, özellikle yetişkinlerin yaşamlarında önemli bir değişken olan okumaya yönelmede ve okumayı sürdürmede okuma motivasyonu temel bir etkendir. Kişilerin okuma amaçları, okuma istekleri, okumayla geçen vakitleri ve okumaya yönelme sebepleri birbiriyle ilişkilidir. Okuma motivasyonu "okuma süreçlerini, sonuçlarını ve konularını etkileyen kişisel amaçlar, değerler ve inançlar" olarak ifade edilmektedir. Yetişkinleri etkileyen okuma motivasyonu boyutlarının içsel ve dışsal motivasyon süreçleriyle öz düzenleme sürecinden ne düzeyde etkilendiğinin belirlenmesi gerekir (Yıldız, Yıldırım, Ateş \& Çetinkaya, 2013).

21. yüzyılda teknolojinin ilerlemesiyle beraber insanlar hayatlarının birçok bölümünde interneti kullanmaktadır. İnternet, insanların hayatlarını kolaylaştırmakla beraber insanlar için vazgeçilmez bir kaynak olmuştur (Kılıç Çakmak, Karaoğlan Yılmaz \& Yılmaz, 2015: 59). İnternet sayesinde kullanılan sosyal medyanın kullanımı oldukça yaygınlaşmıştır (Balcı \& Ayhan, 2007; Govani \& Pashley, 2007; Mazman \& Usluel, 2009; Vural \& Bat, 2010; Akyazı \& Ünal, 2013; Otrar \& Argın, 2014; Tektaş, 2014; Aydın, 2016). Özellikle lise ve üniversite öğrencileri arasında sosyal medya kullanımının diğer yaş aralıklarına göre daha fazla olduğu görülmektedir. Günümüzde sosyal medya kullanımının artmasıyla birlikte bilgiye ulaşabilmek oldukça kolaylaşmıştır. Çünkü sosyal medyada kullanıcıların hepsi sahip oldukları bilgileri paylaşma olanağına sahiptir. Sosyal medyadaki bilgilerin çeşitlilik göstermesinden dolayı sosyal medya kullanıcılarının bu bilgilerin hangilerinin doğru ya da yanlış olduğunu kavraması oldukça güçtür. Bu yüzden sosyal medyadan edinilen bilgilerin doğruluğunun sorgulanması bir hayli önemlidir. Sosyal medyayı kullananlar arasında öğretmen adayları da yer almaktadır.

Bilim, teknolojinin gelişmesiyle beraber sürekli kendini geliştirip değiştirmektedir (Terzi, 2005: 299). Çağdaş bilim anlayışında bilimsel bilginin değişilebilir olduğu, araştırmacıların öznel yaklaşımlarda bulundukları da göz önünde tutulmalıdır (Yenice, Alpak Tunç \& Yavaşoğlu, 2018: 133-134). Epistemoloji; bilimin kaynağını, koşullarını ve doğasını araştıran bir bilim dalıdır (Oksal, Şenşekerci \& Bilgin, 2006: 372-373). 
Epistemolojik inançlar ise bireylerin bilime karşı olan inançlarını (Terzi, 2005: 299) ve bilginin oluşum sürecindeki inançları kapsamaktadır (Deryakulu \& Büyüköztürk, 2005: 58; Aypay, 2011: 1). Perry (1981) epistemolojik inançların zekâ, öğretme ve öğrenmeye bağlı olarak değiştiğini ileri sürmektedir (Aktaran, Oksal vd., 2006: 373). Reybold (2002) ise epistemolojik inancın var olma, ilgili davranış ve eylemleri geliştirme süreci olduğunu ifade etmektedir (Aktaran Başbay, 2013: 251). Bu bağlamda yapılan çalışmalar da göz önünde tutulduğunda epistemolojik inanç; bireyin bilgiyi tanımlayabilmesini, öğrendiği ve edindiği bilgilerin gerçek anlamda nereden geldiğini, bilginin nerede ve nasıl durduğunu sorgulayabilmesini ifade etmektedir.

Literatür incelendiğinde epistemolojiyle ilgili birçok çalışmanın yapıldı̆̆ görülmektedir (Deryakulu, 2002; Deryakulu \& Büyüköztürk, 2005; Demir, 2012; Kılıç Çakmak vd., 2015: 59; Sezgin, Ayğar \& Gündoğdu, 2019: 277). Öğretmen adaylarının, öğrenme konusunda öğrenciler ile iletişim içinde olacaklarından, bu konuda yeterli bilgi sahibi olmaları gerekmektedir. Öğretmen adaylarının epistemolojik inançlarının belirlenmesi, onların gelişimi için önemlidir (Koç \& Memduhoğlu, 2017: 120). Schommer'e (1994) göre olgunlaşmış inanç eğilimine sahip bireyler; eleştirel okurlar, deneyimlidirler, bilginin değişebileceğine inanırlar. Olgunlaşmamış inanç eğilimine sahip bireyler ise deneyimsizdirler, bilginin sadece küçük bir kısmının değişebileceğine inanırlar, etkilenmeye açıktırlar, okuduklarına eleştirel bir gözle yaklaşmazlar ve bilgiye sorgulayıcı gözle bakmadıkları için kolayca inandırılabilirler (Akt. Aypay 2011: 2). Buna göre gelişmiş epistemolojik inançlara sahip bir birey, "öğreneceği bilgiyi nasıl öğrenmesi ve öğrenirken hangi stratejiyi kullanması gerektiğini bilir, öğrendiği bilgilerin doğruluğunu araştırabilir, bilginin değişebilir olduğu bilgisine ulaşabilir ve bilginin bir öğretici tarafından doğrudan aktarılamayacağını bilir" diyebiliriz. Epistemolojik inançlar konusunda biraz daha zayıf bireyler ise üst düzey düşünme becerilerini daha az kullanır, bilginin değişmez ve kesin olduğu bilgisine ve bilginin bir öğretici tarafindan doğrudan aktarılabileceğine inanır, öğrendiği bilgilerin doğruluğunu araştırmayı ve nasıl araştırması gerektiğini tam olarak bilmeyebilir ve bilgiyi öğrenirken kullanacağı stratejiyi tam olarak seçemeyebilir.

Araştırmanın amacı, Türkçe öğretmeni adaylarının okuma motivasyonu düzeyleri ve sosyal medyaya özgü epistemolojik inançları arasındaki ilişkinin belirlenmesidir. Günümüzde öğretmen adaylarının okuma yaptıkları alanlar teknolojinin gelişmesiyle birlikte çoğalmaktadır. İnternet ve sosyal medya kullanımı oldukça arttığı için bireyler internette ve sosyal medyada zaman geçirirken istedikleri pek çok konuda okuyarak bilgi sahibi olmaktadır. Bu durumun onların okuma motivasyonlarını etkileyip etkilemediği sorusu akla gelmektedir. Ayrıca okuyucular tarafından bilgi çeşitliliğinden dolayı sosyal medyadaki bilgilerin ve bilgi kaynaklarının doğruluk açısından incelenmesi gerekmektedir. Sosyal medya kullanımı daha çok lise ve üniversite öğrencileri arasında yaygın olduğu için doğal olarak Türkçe öğretmeni adayları da sosyal medyayı çok kullanmaktadır ama okudukları, öğrendikleri bilgilerin doğruluğunu ne kadar araştırdıkları bilinmemektedir. Bu yüzden Türkçe öğretmeni adaylarının okuma motivasyonu düzeylerinin ve sosyal medyaya özgü epistemolojik inançlarının belirlenmesi bu konuda bilgi sahibi olunmasını sağlayacaktır. 


\section{Yöntem}

\section{Araştırmanın Modeli}

$\mathrm{Bu}$ araştırmada, Türkçe öğretmeni adaylarının okuma motivasyonu düzeyleri ve sosyal medyaya özgü epistemolojik inançları arasındaki ilişkiyi belirlemek amacıyla nicel araştırma yöntemlerinden ilişkisel tarama modeli kullanılmıştır. Bir gruba ait özelliklerin tanımlayıcı analizler yoluyla belirlenmesine yönelik yapılan araştırmalara, tarama araştırması denir (Büyüköztürk, Kılıç Çakmak, Akgün, Karadeniz \& Demirel, 2018: 15). İlişkisel taramada ise değişkenlerle çalışmaya katkı sağlayanların görüşleri arasındaki ilişkiler incelenir (Karasar, 2007: 81). Bu araştırmada Türkçe öğretmeni adaylarının okuma motivasyonu düzeyleri ve sosyal medyaya özgü epistemolojik inançları arasındaki ilişki ve bu iki ölçek verileri ile değişkenler arasındaki ilişki incelenmiştir.

\section{Örneklem}

Araştırmanın örneklem grubunda, Türkiye'nin batısında yer alan bir devlet üniversitesinde öğrenim gören 209 Türkçe öğretmeni adayı yer almaktadır. Araştırmanın örneklem grubuna dair tanımlayıcı istatistik analizleri verilmiştir.

Tablo 1. Araştırmaya Katılanların Cinsiyetleri ile İlgili Tanımlayıcı İstatistik Analizleri

\begin{tabular}{ccc}
\hline Cinsiyet & $f$ & $\%$ \\
\hline Kadın & 143 & 68,4 \\
Erkek & 66 & 31,6 \\
\hline
\end{tabular}

Tablo 1 incelendiğinde öğretmen adaylarının \%68.4'ünün kadın, \%31.6'sının erkek olduğu görülmektedir.

Tablo 2. Araştırmaya Katılanların Yaşamlarını Geçirdikleri Yerle İlgili Tanımlayıcı İstatistik Analizleri

\begin{tabular}{ccc}
\hline Yaşamın Geçirildiği Yer & $f$ & $\%$ \\
\hline Köy & 30 & 14,4 \\
Kasaba & 30 & 14,4 \\
Şehir & 78 & 37,3 \\
Büyükşehir & 71 & 34,0 \\
\hline
\end{tabular}

Tablo 2 incelendiğinde öğretmen adaylarının yaşamının çoğunu \%14.4'ünün köyde, \%14.4'ünün kasabada, \%37.3'ünün şehirde, \%34'ünün ise büyükşehirde geçirdiği görülmektedir.

Tablo 3. Araştırmaya Katılanların Kardeş Sayısı

\begin{tabular}{ccc}
\hline Kardeș Sayısı & $f$ & $\%$ \\
\hline 1 & 15 & 7,2 \\
2 & 97 & 46,4 \\
3 & 57 & 27,3 \\
4 ve üzeri & 40 & 19,1 \\
\hline
\end{tabular}

Tablo 3 incelendiğinde öğretmen adaylarının \%7.2'sinin tek, \%46.4'ünün 2, \%27.3'ünün 3, \%19.1'inin ise 4 ve üzeri kardeş oldukları görülmektedir.

Tablo 4. Araştırmaya Katılanların Anne ve Babalarının Eğitim Durumu

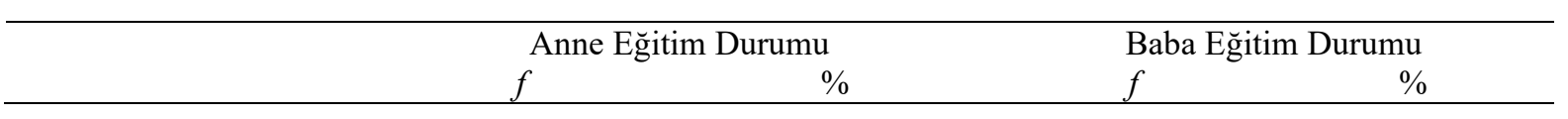




\begin{tabular}{ccccc}
\hline Okur-Yazar Değil & 12 & 5,7 & & \\
Okur-Yazar & 11 & 5,3 & 86 & 41,1 \\
Ilkokul Mezunu & 126 & 60,3 & 53 & 25,4 \\
Ortaokul Mezunu & 23 & 11,0 & 43 & 20,6 \\
Lise Mezunu & 31 & 14,8 & 27 & 12,9 \\
Üniversite Mezunu & 6 & 2,9 & 27 \\
\hline
\end{tabular}

Tablo 4 incelendiğinde öğretmen adaylarının annelerinin \%5.7'sinin okur-yazar olmadığı; \%5.3'ünün okur-yazar, \%60.3'ünün ilkokul, \%11'inin ortaokul, \%14.8'inin lise, \%2.9'unun üniversite mezunu olduğu görülmektedir. Öğretmen adaylarının babalarının ise \%41.1'inin ilkokul, \%25.4'ünün ortaokul, \%20.6'sının lise, \%12.9'unun üniversite mezunu olduğu görülmektedir.

Tablo 5. Araştırmaya Katılanların Sınıf Düzeyi ve Not Ortalaması

\begin{tabular}{cccccc}
\hline Sinıf Düzeyi & \multicolumn{5}{c}{ Not Ortalamas1 } \\
\hline 1 & $f$ & $\%$ & & $f$ & $\%$ \\
2 & 31 & 14,8 & $0-2,5$ & 12 & 5,7 \\
3 & 53 & 25,4 & $2,51-3,00$ & 77 & 36,8 \\
4 & 61 & 29,2 & $3,01-4,00$ & 120 & 57,4 \\
\hline
\end{tabular}

Tablo 5 incelendiğinde öğretmen adaylarının sınıf düzeylerinin \%14.8'inin 1., \%25.4'ünün 2., \%29.2'sinin 3., \%30.6'sının 4. sınıf olduğu görülmektedir. Öğretmen adaylarının not ortalamalarının ise \%5.7'sinin 0-2.5 arasında, \%36.8'inin 2.51-3.00 arasında, \%57.4'ünün ise 3.01-4.00 arasında olduğu görülmektedir.

Tablo 6. Araştırmaya Katılanların Yı1lık Okudukları Kitap Sayısı

\begin{tabular}{ccc}
\hline Okunan Kitap Sayıs1 & $f$ & $\%$ \\
\hline $0-5$ & 35 & 16,7 \\
$6-10$ & 59 & 28,2 \\
$11-15$ & 51 & 24,4 \\
16 ve üzeri & 64 & 30,6 \\
\hline
\end{tabular}

Tablo 6 incelendiğinde öğretmen adaylarının y1lda \%16.7'sinin 0-5 arası, \%28.2'sinin 6-10 aras1, \%24.4'ünün 11-15 aras1, \%30.6'sının ise 16 ve üzeri kitap okuduğu görülmektedir.

Tablo 7. Araştırmaya Katılanların Bir Günde Sosyal Medya ve İnternette Geçirdikleri Süre

\begin{tabular}{ccccc}
\hline & \multicolumn{2}{c}{ Sosyal Medyada Geçirilen Süre } & \multicolumn{2}{c}{ İnternette Geçirilen Süre } \\
Zaman Dilimi & $f$ & $\%$ & $F$ & 11,5 \\
\hline $0-1$ & 41 & 19,6 & 24 & 32,1 \\
$2-3$ & 92 & 44,0 & 67 & 42,6 \\
$4-6$ & 70 & 33,5 & 89 & 13,9 \\
7 üzeri & 6 & 2,9 & 29 & \\
\hline
\end{tabular}

Tablo 7 incelendiğinde öğretmen adaylarının bir günde sosyal medyada geçirdikleri sürenin \%19.6'sının 0-1 saat arasında, \%44'ünün 2-3 saat arasında, \%33.5'inin 4-6 saat arasında, \%2.9'unun ise 7 saat üzerinde olduğu görülmektedir. Öğretmen adaylarının bir günde internette geçirdikleri sürenin \%11.5'inin 0-1 saat arasında, \%32.1'inin 2-3 saat arasında, \%42.6'sının 4-6 saat arasında, \%13.9'unun ise 7 saat üzerinde olduğu görülmektedir.

\section{Veri Toplama Araçları}




\section{Kişisel Bilgi Formu}

Araştırmacı tarafından hazırlanan kişisel bilgi formunda, öğretmen adaylarının cinsiyetine, yaşamını daha çok nerede geçirdiğine, anne ve babasının mesleğine, kardeş sayısına, sınıf düzeyine, anne ve babasının eğitim durumuna, not ortalamasına, yılda okudukları kitap sayısına, sosyal medya ve internette geçirdikleri günlük süreye, kitap okuma amaçlarına, kitabı daha çok nereden, ne zaman ve nerede okumak istediklerine yönelik sorular yer almaktadır.

\section{Yetişkin Okuma Motivasyonu Ölçeği}

Araştırmada Yıldız, Yıldırım, Ateş \& Çetinkaya (2013) tarafından Türkçeye uyarlanan Yetişkin Okuma Motivasyonu Ölçeği, kendilerinden izin alınarak veri toplama aracı olarak kullanılmıştır. Yıldız vd. (2013) tarafından Türkçeye uyarlanan ölçek, 19 madde ve 4 alt boyuttan oluşmaktadır. Ölçekten elde edilen verilere göre faktörler, kendinin bir parçası olarak okuma (benlik), okuma yeterliliği (yeterlilik), tanınmak için okuma (tanınma) ve diğer alanlarda iyi işler gerçekleştirmek için okuma (diğer) olarak isimlendirilmiştir. Ölçek uygulaması için gerekli izinler alındıktan sonra araştırmacılar tarafından ölçeğe açımlayıcı faktör analizi yapılmıştır. Yapılan Kaiser-Meyer-Olkin $(\mathrm{KMO}=.89)$, Bartlett testi $\left(\mathrm{x}^{2}=2007,657 ; \mathrm{sd}=171 \quad(\mathrm{p}=.000)\right.$ analiz sonucunda ölçeğin yap1 geçerliğinin uygun olduğu görülmüştür. Ölçek, toplam varyansın 63.492'sini açıklamaktadır.

\section{Sosyal Medyaya Özgü Epistemolojik Ínançlar Ölçeği}

Araştırmada, Çelik (2019) tarafından geliştirilen Sosyal Medyaya Özgü Epistemolojik Inançlar Ölçeği izin alınarak bir diğer veri toplama aracı olarak kullanılmıştır. Araştırmacı, sosyal medyaya özgü epistemolojik inançları temsil ettiği düşünülen toplam 15 maddeden oluşan 5'li likert tipi bir ölçek elde etmiştir. Ölçek, sosyal medya tabanlı bilginin basitliği ve kesinliği, bilginin kaynağı ve bilmenin kanıtı olmak üzere 3 alt boyuttan oluşmaktadır. Ölçek uygulaması için gerekli izinler alındıktan sonra araştırmacılar tarafından ölçeğe açımlayıcı faktör analizi yapılmıştır. Yapılan KaiserMeyer-Olkin $(\mathrm{KMO}=.83)$, Bartlett testi $\left(\mathrm{x}^{2}=1169,560 ; \mathrm{sd}=105(\mathrm{p}=.000)\right.$ analiz sonucunda ölçeğin yapı geçerliğinin uygun olduğu görülmüştür. Ölçek, toplam varyansın 57.212'sini açıklamaktadır.

\section{Verilerin Analizi}

Yetişkin Okuma Motivasyonu ve Sosyal Medyaya Özgü Epistemolojik İnançlar Ölçeği'nden alınan puanların güvenirliğini belirlemek için, Cronbach Alfa iç tutarlılık hesaplamaları yapılmıştır. Yetişkin Okuma Motivasyonu Ölçeği’nin 19 maddelik hesaplanan Cronbach Alfa değeri 0.90 şeklindedir. Cronbach Alfa değerinin 0.80'in üzerinde olması ölçeğin güvenilir olduğunu göstermektedir denilebilir $(\mathrm{p}<0.05)$. Sosyal Medyaya Özgü Epistemolojik İnançlar Ölçeği'nin 15 maddelik hesaplanan Cronbach Alfa değeri 0.76 şeklindedir. Araştırmadan elde edilen verilerin normal dağılım gösterip göstermediğini belirlemek için çarpıklık ve basıklık değerleri hesaplanmıştır. Literatürde verilerin normal dağılım gösterebilmesi için çarpıklık ve basıklık değerlerinin -2 ile +2 arasında değişmesi gerektiği belirtilmektedir (Şencan, 2005). Araştırmada kullanılan ölçeklerden elde edilen verilere göre ölçeğin normallik şartını sağladığı görülmektedir. 
Tablo 8. Ölçeklere Ait Çarpıklık (Skewness) ve Basıklık (Kurtosis) Değerleri

\begin{tabular}{cccc}
\hline Ölçekler & Boyutlar & $\begin{array}{c}\text { Carpıklık } \\
\text { (Skewness) }\end{array}$ & $\begin{array}{c}\text { Basıklık } \\
\text { (Kurtosis) }\end{array}$ \\
\hline \multirow{2}{*}{ Yetişkin Okuma Motivasyonu } & Benlik &,- 767 &,- 093 \\
Ölçeği & Yeterlilik &,- 386 &, 215 \\
& Tanınma &,- 044 &,- 802 \\
& Diğer &,- 662 &, 152 \\
Sosyal Medyaya Özgü & Sosyal Medya Tabanlı Bilginin &, 708 & 1,398 \\
Epistemolojik İnançlar Ölçeği & Basitliği ve Kesinliği &, 744 &, 654 \\
& Bilginin Kaynağı &,- 800 &, 576 \\
\hline
\end{tabular}

Tablodan da görüleceği üzere araştırmanın verileri normal dağılım göstermektedir. Araştırmanın verileri normal dağılım gösterdiği için analizlerde parametrik testler uygulanacaktır. Araştırmada elde edilen verilere açımlayıcı faktör analizi, tanımlayıcı istatistiksel analizler, t-testi ve ANOVA istatistiksel analizleri yapılmıştır. Araştırmada ayrıca korelasyon analizi yapılmıştır.

Türkçe öğretmeni adaylarının okuma motivasyonlarının ve sosyal medyaya özgü epistemolojik inançlarının cinsiyet ve anne mesleği değişkenlerine göre anlamlı bir farklılık gösterip göstermediği bağımsız t-testi analizi ile; yaşamlarını nerede geçirdikleri, babalarının mesleği, kardeş sayısı, anne ve babalarının eğitim durumu, not ortalaması, sınıf düzeyi, kitap okuma sayısı, sosyal medyada ve internette geçirilen süre değişkenlerine göre anlamlı bir farklılık gösterip göstermediği ise tek yönlü varyans analizi (ANOVA) ile incelenmiştir. Veriler, SPSS25 paket programı yoluyla analiz edilmiştir. İki ölçek verileri arasında ilişkinin olup olmadığını tespit etmek amacıyla korelasyon analizi yapılmıştır. Korelasyon analizi, iki değişken arasındaki ilişkinin yönünü ve gücünü ölçmede kullanılan analiz tekniğidir. Korelasyon analizinde korelasyon katsayısı " $r$ " olarak gösterilmektedir. $\mathrm{Bu}$ analizde ilişki (-1) ile (+1) arasında olabilir. Değişkenler arasındaki r değerinin 0.000.29 arasında olması düşük, 0.30-0.69 arasında olması orta, 0.70 ve üzerinde olması ise “yüksek” düzeyde ilişkinin olduğu yönündedir (Ural ve Kılıç, 2006).

\section{Etik Kurulu İzni}

Araştırmada uygulanan ölçeklerle ilgili ölçek sahiplerinden gerekli izinler alınmıştır. Araştırma Eğitim Fakültesi'nde öğrenim gören öğretmen adaylarıyla gerçekleştiği için Eğitim Fakültesi'nden ölçeklerin uygulanmasıyla ilgili gerekli izinler alınmıştır. Çanakkale Onsekiz Mart Üniversitesi Sosyal Bilimler ve Eğitim Bilimleri Etik Kurulu 16.04.2020 tarih, 03 numaralı toplantısında (Başvuru Protokol Numarası:2020/035) araştırmanın bilimsel etik kurallara uygun olduğu kararı verilmiştir.

\section{Bulgular}

Araştırmanın bu bölümünde araştırmadan elde edilen veriler analiz edilecek ve yorumlanacaktır.

Tablo 9. Araştırmaya Katılanların Kitap Okuma Amaçları 
Bilgi Sahibi Olmak ve Merak Duygusunu Gidermek İçin

Keyifli Zaman Geçirmek İçin

Söz Dağarcığını ve Diksiyonu Geliştirmek İçin

Bakış Açısını ve Hayal Dünyasını Genişletmek İçin

Boş Zamanı Değerlendirmek ve Verimli Zaman Geçirmek İçin $\quad 21 \quad 10,0$

Diğer

$15 \quad 7,2$

Tablo 9 incelendiğinde öğretmen adaylarının \%30,6'sının bilgi sahibi olmak ve merak duygusunu gidermek için; \%20,6'sının keyifli zaman geçirmek için; \%18,7'sinin söz dağarcığını ve diksiyonunu geliştirmek için; \%12,9'unun bakış açısını ve hayal dünyasını genişletmek için; \%10'unun boş zamanını değerlendirmek ve verimli zaman geçirmek için; \%7,2'sinin ise diğer sebeplerden dolayı kitap okudukları görülmektedir.

Tablo 10. Araştırmaya Katılanların Daha Çok Nereden Okumayı Sevdikleri

\begin{tabular}{ccc}
\hline Nereden Okumayı Sevdikleri & $f$ & $\%$ \\
\hline Kitap & 147 & 70,3 \\
Diğer & 39 & 18,7 \\
Telefon & 23 & 11,0 \\
\hline
\end{tabular}

Tablo 10 incelendiğinde öğretmen adaylarının \%70,3'ünün kitaptan, 18,7'sinin diğer yerlerden, \%11'inin ise telefondan okumayı sevdikleri görülmektedir.

Tablo 11. Araştırmaya Katılanların Daha Çok Ne zaman Okumayı Sevdikleri

\begin{tabular}{ccc}
\hline Ne zaman Okumayı Sevdikleri & $f$ & $\%$ \\
\hline Herhangi Bir Zamanda & 61 & 29,2 \\
Boş Zamanlarda & 59 & 28,2 \\
Diğer & 46 & 22,0 \\
Akşam & 43 & 20,6 \\
\hline
\end{tabular}

Tablo 11 incelendiğinde öğretmen adaylarının \%29,2'sinin herhangi bir zamanda, \%28,2'sinin boş zamanlarda, \%22'sinin diğer zamanlarda, \%20,6'sının akşam okumayı sevdikleri görülmektedir.

Tablo 12. Araştırmaya Katılanların Daha Çok Nerede Okumayı Sevdikleri

\begin{tabular}{ccc}
\hline Nerede Okumayı Sevdikleri & $\mathrm{f}$ & $\%$ \\
\hline Diğer & 109 & 52,2 \\
Evde-Odada-Yurtta & 76 & 36,4 \\
Sessiz Bir Ortamda & 24 & 11,5 \\
\hline
\end{tabular}

Tablo 12 incelendiğinde öğretmen adaylarının \%52,2'sinin diğer yerlerde, \%36,4'ünün evde-odada ya da yurtta, \%11,5'inin ise sessiz bir ortamda okumayı sevdikleri görülmektedir.

\section{Yetişkin Okuma Motivasyonu Ölçeği Analizleri}

Tablo 13. Benlik Boyutuna Ait Tanımlayıcı İstatistik Analizleri

\begin{tabular}{clrrc}
\hline $\begin{array}{c}\text { Boyut } \\
\text { Adı }\end{array}$ & \multicolumn{1}{c}{ Maddeler } & $\overline{\mathrm{x}}$ & ss & $\begin{array}{c}\text { Genel } \\
\text { Ortalama }\end{array}$ \\
\hline & Okuma olmasaydı hayatım aynı olmazdı. & 4,36 & 0,9 & \\
& Okumak hayatımı daha anlamlı kılar. & 4,28 & 0,79 & 3,87 \\
$\bar{D}$ & Diğer etkinliklerle kıyaslarsak okuma benim için önemlidir. & 4,09 & 0,94 & \\
& Okuyarak diğer insanlara iyi örnek olurum. & 3,92 & 1,02 & \\
\hline
\end{tabular}




$\begin{array}{llc}\text { Hızlı okurum. } & 3,84 & 0,83 \\ \text { Arkadaşlarım ve ben, özellikle hoşumuza giden kitap ve makaleleri } & 3,34 & 1,23 \\ \text { değiş tokuş etmekten zevk alırız. } & 3,14 & 0,92 \\ \text { Benim için okumaya vakit ayırmak önemlidir. } & 2,97 & 1,23 \\ \text { Bazen arkadaşlarım ne kadar çok okuduğuma şaşırırlar. } & \end{array}$

Tablo 13 incelendiğinde öğretmen adayları okumayı hayatının merkezine koydukları görülmektedir. Öğretmen adayları okumanın hayatlarını daha anlamlı kıldığını, diğer etkinliklere kıyasla önemli olduğunu, okuyarak örnek olduklarını, hızlı okuduklarını, hoşlarına giden kitap ve makaleleri arkadaşları arasında değiş-tokuş yaptıklarını, okumaya vakit ayırdıklarını ifade etmektedirler. Öğretmen adayları arkadaşlarını şaşırtacak kadar kitap okumadıklarını belirtmektedirler.

Tablo 14. Yeterlilik Boyutuna Ait Tanımlayıcı İstatistik Analizleri

\begin{tabular}{|c|c|c|c|c|}
\hline $\begin{array}{l}\text { Boyut } \\
\text { Ad1 }\end{array}$ & Maddeler & $\overline{\mathrm{x}}$ & ss & $\begin{array}{c}\text { Genel } \\
\text { Ortalama }\end{array}$ \\
\hline \multirow{4}{*}{ 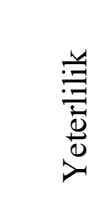 } & $\begin{array}{l}\text { Bir kitap veya makale ilgi çekiciyse, ne kadar zor okunduğu } \\
\text { umurumda olmaz. }\end{array}$ & 3,88 & 0,96 & \multirow{4}{*}{3,55} \\
\hline & İyi bir okuyucuyumdur. & 3,72 & 0,95 & \\
\hline & Zor, düşündürücü kitap ve makaleleri severim. & 3,37 & 1,12 & \\
\hline & Zor kitap ve makaleleri anlayabildiğimden eminim. & 3,24 & 1,00 & \\
\hline
\end{tabular}

Tablo 14 incelendiğinde öğretmen adayları okuma konusunda kendilerini yeterli görmektedirler. İlgi çekici bir makaleyi okumanın zor almadığını; iyi bir okuyucu olduklarını; zor, düşündürücü kitap ve makaleleri sevdiklerini ifade etmektedirler. Öğretmen adayları zor kitap ve makaleleri anlayabildiklerinden emin değildirler.

Tablo 15. Tanınma Boyutuna Ait Tanımlayıcı İstatistik Analizleri

\begin{tabular}{|c|c|c|c|c|}
\hline $\begin{array}{l}\text { Boyut } \\
\text { Ad1 }\end{array}$ & Maddeler & $\overline{\mathrm{x}}$ & ss & $\begin{array}{c}\text { Genel } \\
\text { Ortalama } \\
\end{array}$ \\
\hline \multirow{3}{*}{ 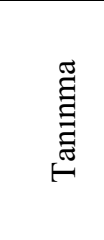 } & $\begin{array}{l}\text { Okuduklarım hakkında başkalarının bana soru sorması hoşuma } \\
\text { gider cünkü bu savede bilgimi gösterebilirim. }\end{array}$ & 3,68 & 1,16 & \multirow{3}{*}{3,10} \\
\hline & $\begin{array}{l}\text { Benim için okuduklarımdan edindiğim bilgiler hakkında övgü } \\
\text { almak önemlidir. }\end{array}$ & 3,11 & 1,29 & \\
\hline & $\begin{array}{l}\text { Benim için diğer insanların ne kadar çok okuduğum hakkında } \\
\text { yorum yapması önemlidir. }\end{array}$ & 2,52 & 1,32 & \\
\hline
\end{tabular}

Tablo 15 incelendiğinde öğretmen adayları tanınmak için okuduklarını, bu doğrultuda okuduklarıyla ilgili soru sorulmasının hoşlarına gideceğini, okudukları hakkında övgü almanın önemli olduğunu belirtmektedirler. Öğretmen adayları, diğer insanların okudukları hakkında yorum yapmasının önemli olmadığını ifade etmektedirler.

Tablo 16. Diğer Boyutuna Ait Tanımlayııı İstatistik Analizleri

\begin{tabular}{|c|c|c|c|c|}
\hline $\begin{array}{l}\text { Boyut } \\
\text { Ad1 }\end{array}$ & Maddeler & $\overline{\mathrm{x}}$ & ss & $\begin{array}{c}\text { Genel } \\
\text { Ortalama }\end{array}$ \\
\hline \multirow{4}{*}{ 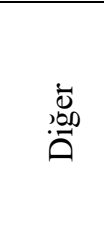 } & $\begin{array}{l}\text { Eğer okuduğum materyaldeki bilgiler bana daha sonra lazım olacaksa, } \\
\text { bunların lazım olacaŏ } 1 \text { zamandan cok önce okumavı bitiririm. }\end{array}$ & 3,87 & 1,05 & \multirow{4}{*}{3,73} \\
\hline & İs veya üniversite performansımı geliştirmek için okurum. & 3,79 & 98 & \\
\hline & $\begin{array}{l}\text { İş performansım veya üniversitede aldığım notlar, okuma etkililiğimin } \\
\text { bir göstergesidir. }\end{array}$ & 3,75 & 1,08 & \\
\hline & İşim veya üniversitedeki derslerim için gerekli tüm okumaları & 3,51 & 1,03 & \\
\hline
\end{tabular}


tamamlarım

Tablo 16 incelendiğinde öğretmen adayları, ihtiyaç olan bilgileri kısa sürede okuyup bitirdiklerini, performanslarını geliştirmek için okuduklarını, aldıkları notların okuma etkililiğinin bir göstergesi olduğunu, gerekli bütün okumaları tamamladıklarını ifade etmektedirler.

Tablo 17. Yetişkin Okuma Motivasyonu Ölçeğindeki Boyutlara İlişkin Cinsiyete Göre t-testi Sonuçları

\begin{tabular}{cccccccc}
\hline Boyut & Cinsiyet & $\mathrm{n}$ & $\overline{\mathrm{x}}$ & $\mathrm{ss}$ & $\mathrm{t}$ & $\mathrm{df}$ & $\mathrm{p}$ \\
\hline \multirow{2}{*}{ Benlik } & Kadın & 143 & 3,95 &, 673 & 2,579 & 207 &, 011 \\
& Erkek & 66 & 3,68 &, 796 & & & \\
\multirow{3}{*}{ Yeterlilik } & Kadın & 143 & 3,52 &, 717 &,- 718 & 207 &, 474 \\
& Erkek & 66 & 3,61 &, 917 & & & \\
\multirow{2}{*}{ Tanınma } & Kadın & 143 & 3,06 & 1,02 &,- 763 & 207 &, 446 \\
& Erkek & 66 & 3,19 & 1,17 & & & \\
\multirow{2}{*}{ Diğer } & Kadın & 143 & 3,84 &, 729 & 3,123 & 207 & 0,02 \\
& Erkek & 66 & 3,48 &, 916 & & & \\
\hline
\end{tabular}

Tablo 17 incelendiğinde öğretmen adaylarının cinsiyetleri ile Yetişkin Okuma Motivasyonu Ölçeğinde yer alan yeterlilik $\left(\mathrm{t}_{(207)}=-718 ; \mathrm{p}>.05\right)$ ve tanınma $\left(\mathrm{t}_{(207)}=-, 763\right.$; p>.05) boyutlarıyla cinsiyet değişkeni arasında anlamlı bir ilişkinin olmadığı görülmektedir. Ölçekte yer alan benlik $\left(\mathrm{t}_{(207)}=2,579 ; \mathrm{p}<.05\right)$ ve diğer $\left(\mathrm{t}_{(207)}=3,123 ; \mathrm{p}<.05\right)$ boyutları arasında anlamlı bir farklılığın olduğu görülmektedir. Kadın öğretmen adayları erkek öğretmen adaylarına göre okumanın hayatın anlamı olduğunu, ne kadar çok okuduklarına bazen arkadaşlarının şaşırdığını, hoşlarına giden makale ya da kitapları arkadaşlarıyla değiş tokuş ettiklerini, okumaya vakit ayırmanın önemli olduğunu, okuyarak diğer insanlara karşı örnek olduklarını, hızlı okuduklarını belirtmektedirler. Kadın öğretmen adayları, erkek öğretmen adaylarına göre ihtiyacı olan materyalleri zamanından önce okuduklarını, performans ve notlarının okuma etkililiğinin bir göstergesi olduğunu, iş ve üniversite için gerekli bütün okumaları yaptıklarını, performanslarını geliştirmek için okuduklarını belirtmektedirler.

Tablo 18. Öğretmen Adaylarının Yaşamlarının Çoğunu Geçirdikleri Yer ile Yetişkin Okuma Motivasyonu Boyutları Arasındaki ANOVA Analizleri

\begin{tabular}{|c|c|c|c|c|c|c|c|}
\hline Değişken & $\begin{array}{c}\text { Varyansın } \\
\text { Kaynağ1 }\end{array}$ & $\begin{array}{l}\text { Kareler } \\
\text { Toplamı }\end{array}$ & $\mathrm{sd}$ & $\begin{array}{c}\text { Kareler } \\
\text { Ortalaması }\end{array}$ & $\mathrm{F}$ & $\mathrm{p}$ & $\begin{array}{l}\text { Anlamlı } \\
\text { Farklılık }\end{array}$ \\
\hline \multirow{3}{*}{ Benlik } & Gruplar arası & 2,213 & 3 &, 738 & 1,415 & ,239 & \\
\hline & Gruplar içi & 106,865 & 205 &, 521 & & & \\
\hline & Toplam & 109,077 & 208 & & & & \\
\hline \multirow{3}{*}{ Yeterlilik } & Gruplar arası & 4,028 & 3 & 1,343 & 2,217 & ,087 & \\
\hline & Gruplar içi & 124,124 & 205 &, 605 & & & \\
\hline & Toplam & 128,152 & 208 & & & & \\
\hline \multirow{3}{*}{ Tanınma } & Gruplar arası & 1,772 & 3 & ,591 & ,510 & ,676 & \\
\hline & Gruplar içi & 237,548 & 205 & 1,159 & & & \\
\hline & Toplam & 239,320 & 208 & & & & \\
\hline \multirow{3}{*}{ Diğer } & Gruplar arası & 6,509 & 3 & 2,170 & 3,426 & ,018 & C-D \\
\hline & Gruplar içi & 129,808 & 205 &, 633 & & & \\
\hline & Toplam & 136,316 & 208 & & & & \\
\hline
\end{tabular}

$A=$ Köy, $B=$ Kasaba, $C=$ Şehir, $D=$ Büyükşehir

Tablo 18 incelendiğinde öğretmen adaylarının yaşamlarının çoğunu geçirdikleri yer ile diğer $(\mathrm{F}=3.426 ; \mathrm{p}<.05)$ boyutundan aldıkları puanlar arasında anlamlı bir ilişkinin olduğu görülmektedir. Tukey testi sonuçlarına göre yaşamlarının çoğunu şehirde geçiren 
öğretmen adayları, yaşamlarının çoğunu büyükşehirde geçiren öğretmen adaylarına göre eğer okudukları materyaldeki bilgiler kendi ihtiyaçlarıysa zamanından önce okumayı tamamladıklarını, iş performanslarının ve üniversitedeki aldığı notların okuma etkililiğinin bir göstergesi olduğunu, iş ve üniversitedeki dersleri için gerekli bütün okumaları tamamladıklarını, iş ve üniversitedeki performanslarını geliştirmek için okuduklarını belirtmektedirler.

Tablo 19. Öğretmen Adaylarının Yaşamlarının Çoğunu Geçirdikleri Yer ile Yetişkin Okuma Motivasyonu Maddeleri Arasındaki ANOVA Analizleri

\begin{tabular}{|c|c|c|c|c|c|c|c|}
\hline Değişken & $\begin{array}{c}\text { Varyansın } \\
\text { Kaynağı }\end{array}$ & $\begin{array}{l}\text { Kareler } \\
\text { Toplamı }\end{array}$ & $\mathrm{sd}$ & $\begin{array}{c}\text { Kareler } \\
\text { Ortalaması }\end{array}$ & $\mathrm{F}$ & $\mathrm{p}$ & $\begin{array}{l}\text { Anlamlı } \\
\text { Farklilık }\end{array}$ \\
\hline \multirow{3}{*}{$\begin{array}{l}\text { Okuma olmasayd } 1 \\
\text { hayatım aynı olmazd1 }\end{array}$} & Gruplar arası & 2,213 & 3 &, 738 & 1,415 & ,239 & D-A \\
\hline & Gruplar içi & 106,865 & 205 &, 521 & & & C-A \\
\hline & Toplam & 109,077 & 208 & & & & B-A \\
\hline \multirow{3}{*}{$\begin{array}{l}\text { Zor kitap ve makaleleri } \\
\text { anlayabildiğimden } \\
\text { eminim }\end{array}$} & Gruplar arası & 1,772 & 3 & ,591 &, 510 & 676 & \\
\hline & Gruplar içi & 237,548 & 205 & 1,159 & & & C-D \\
\hline & Toplam & 239,320 & 208 & & & & \\
\hline
\end{tabular}

$A=$ Köy, $B=$ Kasaba, $C=$ Şehir, $D=$ Büyükşehir

Tablo 19 incelendiğinde öğretmen adaylarının yaşamlarının çoğunu geçirdikleri yer ile "Okuma olmasayd hayatım aynı olmazdı" $(\mathrm{F}=1.415 ; \mathrm{p}<.05)$ ve "Zor kitap ve makaleleri anlayabildiğimden eminim" $(\mathrm{F}=0.510 ; \mathrm{p}<.05)$ maddelerinden aldıkları puanlar arasında anlamlı bir farklılık olduğu sonucuna ulaşılmıştır. Tukey testi sonuçlarına göre yaşamlarının çoğunu büyükşehir, şehir, kasabada geçiren öğretmen adayları, yaşamlarının çoğunu köyde geçiren öğretmen adaylarına göre "okuma olmasaydı hayatlarının aynı olmayacağını" ifade etmektedirler. Aynı şekilde yaşamlarının çoğunu şehirde geçiren öğretmen adayları, yaşamlarının çoğunu büyükşehirde geçiren öğretmen adaylarına göre zor kitap ve makaleleri anlayabildiklerinden emindirler.

Tablo 20. Öğretmen Adaylarının Babalarının Meslekleri ile Yetişkin Okuma Motivasyonu Maddeleri Arasındaki ANOVA Analizleri

\begin{tabular}{|c|c|c|c|c|c|c|c|}
\hline Değişken & $\begin{array}{c}\text { Varyansın } \\
\text { Kaynağ1 }\end{array}$ & $\begin{array}{l}\text { Kareler } \\
\text { Toplamı }\end{array}$ & $\mathrm{Sd}$ & $\begin{array}{c}\text { Kareler } \\
\text { Ortalamas }\end{array}$ & $\mathrm{F}$ & $\mathrm{p}$ & $\begin{array}{l}\text { Anlamlı } \\
\text { Farklılık }\end{array}$ \\
\hline \multirow{3}{*}{$\begin{array}{c}\text { Okuma olmasayd } 1 \\
\text { hayatım aynı olmazdı }\end{array}$} & Gruplar arası & 21,636 & 6 & 3,606 & 4,889 & ,000 & A-B; C-B \\
\hline & Gruplar içi & 148,995 & 202 &, 738 & & & D-B; E-B \\
\hline & Toplam & 170,632 & 208 & & & & F-B; G-B \\
\hline \multirow{3}{*}{ Hizlı okurum } & Gruplar arası & 11,449 & 6 & 1,908 & 2,869 &, 011 & \\
\hline & Gruplar içi & 134,340 & 202 &, 665 & & & $\mathrm{C}-\mathrm{F}$ \\
\hline & Toplam & 145,789 & 208 & & & & \\
\hline
\end{tabular}

A:Emekli, B:Çiftçi, C:Esnaf, D:İş̧̧i, E: Serbest Meslek, F: Memur, G: Diğer

Tablo 21 incelendiğinde katılımcıların babalarının meslekleri ile "Okuma olmasaydl hayatım aynı olmazdı" ( $\mathrm{F}=4.889 ; \mathrm{p}<.05)$ ve "Hızl okurum" $(\mathrm{F}=2.869 ; \mathrm{p}<.05)$ maddelerinden aldıkları puanlar arasında anlamlı bir farklılık olduğu görülmektedir. Tukey testi sonuçlarına göre babalarının meslekleri emekli, esnaf, işçi, serbest meslek, memur ve diğer meslekler olanların, babalarının meslekleri çiftçi olanlara göre okumayı hayatlarının merkezlerine koydukları görülmektedir. Babalarının meslekleri esnaf olan öğretmen adaylarının babalarının meslekleri memur olanlara göre hızlı okuduklarını düşündükleri görülmektedir.

Tablo 21. Öğretmen Adaylarının Kardeş Sayıları ile Yetişkin Okuma Motivasyonu Boyutları Arasındaki ANOVA Analizleri 


\begin{tabular}{|c|c|c|c|c|c|c|c|}
\hline Değişken & $\begin{array}{c}\text { Varyansın } \\
\text { Kaynağ1 }\end{array}$ & $\begin{array}{l}\text { Kareler } \\
\text { Toplamı }\end{array}$ & sd & $\begin{array}{c}\text { Kareler } \\
\text { Ortalamas }\end{array}$ & $\mathrm{F}$ & $\mathrm{p}$ & $\begin{array}{l}\text { Anlaml1 } \\
\text { Farklil1k }\end{array}$ \\
\hline \multirow{3}{*}{ Benlik } & Gruplar aras1 & 1,955 & 3 & 652 & 1,247 & 294 & \\
\hline & Gruplar içi & 107,122 & 205 &, 523 & & & \\
\hline & Toplam & 109,077 & 208 & & & & \\
\hline \multirow{3}{*}{ Yeterlilik } & Gruplar aras1 & 6,061 & 3 & 2,020 & 3,392 & ,019 & D-A \\
\hline & Gruplar içi & 122,091 & 205 & -596 & & & \\
\hline & Toplam & 128,152 & 208 & & & & \\
\hline \multirow{3}{*}{ Tanınma } & Gruplar aras1 & 8,463 & 3 & 2,821 & 2,505 &, 060 & \\
\hline & Gruplar içi & 230,857 & 205 & 1,126 & & & \\
\hline & Toplam & 239,320 & 208 & & & & \\
\hline \multirow{3}{*}{ Diğer } & Gruplar aras1 & 3,062 & 3 & 1,021 & 1,570 & ,198 & \\
\hline & Gruplar içi & 133,255 & 205 & 650 & & & \\
\hline & Toplam & 136,316 & 208 & & & & \\
\hline
\end{tabular}

$A: 1, B: 2, C: 3, D: 4$ ve üzeri

Tablo 21 incelendiğinde öğretmen adaylarının kardeş sayıları ile benlik $(\mathrm{F}=1.247$; $\mathrm{p}>.05)$, tanınma $(\mathrm{F}=2.505 ; \mathrm{p}>.05)$, diğer $(\mathrm{F}=1.570 ; \mathrm{p}>.05)$ boyutlarından aldıkları puanlar arasında anlamlı bir ilişkinin olmadığı görülmektedir. Öğretmen adaylarının kardeş sayıları ile yeterlilik $(\mathrm{F}=3.392 ; \mathrm{p}<.05)$ boyutundan aldıkları puanlar arasında anlamlı bir ilişkinin olduğu görülmektedir. Tukey testi sonuçlarına göre 4 ve üzeri kardeş olan öğretmen adayları 2 kardeş olan öğretmen adaylarına göre kendilerini iyi okuyucu olarak gördüklerini; zor kitap ve makaleleri hem sevip hem de anlayabildiklerini; ilgi çekiciliğin kitap ve makale okumada etkisi olduğunu düşündüklerini belirtmişlerdir.

Tablo 22. Öğretmen Adaylarının Babalarının Eğitim Durumu ile Yetişkin Okuma Motivasyonu Maddeleri Arasındaki ANOVA Analizleri

\begin{tabular}{|c|c|c|c|c|c|c|c|}
\hline Değişken & $\begin{array}{c}\text { Varyansın } \\
\text { Kaynağ }\end{array}$ & $\begin{array}{l}\text { Kareler } \\
\text { Toplam1 }\end{array}$ & $\mathrm{Sd}$ & $\begin{array}{c}\text { Kareler } \\
\text { Ortalamas1 }\end{array}$ & $\mathrm{F}$ & $\mathrm{p}$ & $\begin{array}{l}\text { Anlamlı } \\
\text { Farklılık }\end{array}$ \\
\hline Bazen arkad & Gruplar arası & 14,295 & 3 & 4,765 & 3,250 & ,023 & A-D \\
\hline kadar çok okuduğuma & Gruplar içi & 300,585 & 205 & 1,466 & & & B-D \\
\hline şaşırırlar & Toplam & 314,880 & 208 & & & & \\
\hline & Gruplar aras1 & 8,241 & 3 & 2,747 & 4,094 &, 008 & B-A \\
\hline Hizlı okurum & Gruplar içi & $\begin{array}{l}137,548 \\
145789\end{array}$ & 205 & 671 & & & B-D \\
\hline
\end{tabular}

A:Illkokul, B:Ortaokul, C: Lise, D: Üniversite

Tablo 22 incelendiğinde öğretmen adaylarının babalarının eğitim durumu ile "Bazen arkadaşlarım ne kadar çok okuduğuma şaşırırlar" (F=3.250; p<.05), "Hızlı okurum" ( $\mathrm{F}=4.094 ; \mathrm{p}<.05)$ maddelerinden aldıkları puanlar arasında anlamlı bir ilişkinin olduğu görülmektedir. Tukey çoklu karşılaştırma testine göre babası ilkokul ve ortaokul mezunu olan katılımcıların, babası üniversite mezunu olan katılımcılara göre daha çok kitap okuduğu görülmektedir. Babası ortaokul mezunu olan katılımcılar, babası ilkokul ve üniversite mezunu olan katılımcılara göre daha hızlı kitap okuduklarını ifade etmektedirler.

Tablo 23. Öğretmen Adaylarının Not Ortalamaları ile Yetişkin Okuma Motivasyonu Boyutları Arasındaki ANOVA Analizleri

\begin{tabular}{|c|c|c|c|c|c|c|c|}
\hline Değişken & $\begin{array}{l}\text { Varyansın } \\
\text { Kaynağı }\end{array}$ & $\begin{array}{l}\text { Kareler } \\
\text { Toplamı }\end{array}$ & sd & $\begin{array}{c}\text { Kareler } \\
\text { Ortalaması }\end{array}$ & $\mathrm{F}$ & $\mathrm{p}$ & $\begin{array}{l}\text { Anlamlı } \\
\text { Farklılık }\end{array}$ \\
\hline \multirow{3}{*}{ Benlik } & Gruplar arası & 6,093 & 2 & 3,047 & 6,094 & ,003 & C-A \\
\hline & Gruplar içi & 102,984 & 206 &, 500 & & & \\
\hline & Toplam & 109,077 & 208 & & & & \\
\hline \multirow{3}{*}{ Yeterlilik } & Gruplar arası & ,688 & 2 & ,344 & ,556 & ,574 & \\
\hline & Gruplar içi & 127,464 & 206 & 619 & & & \\
\hline & Toplam & 128,152 & 208 & & & & \\
\hline
\end{tabular}




\begin{tabular}{|c|c|c|c|c|c|c|c|}
\hline \multirow{3}{*}{ Tanınma } & Gruplar arası & 2,791 & 2 & 1,396 & 1,215 & ,299 & \\
\hline & Gruplar içi & 236,528 & 206 & 1,148 & & & \\
\hline & Toplam & 239,320 & 208 & & & & \\
\hline \multirow{3}{*}{ Diğer } & Gruplar arası & 15,553 & 2 & 7,777 & 13,265 &, 000 & B-A \\
\hline & Gruplar içi & 120,763 & 206 & ,586 & & & C-A \\
\hline & Toplam & 136,316 & 208 & & & & C-B \\
\hline
\end{tabular}

A:0-2.50, B: 2.51-2.99, C: 3.00-4.00

Tablo 23 incelendiğinde katılımcıların not ortalamaları ile benlik $(\mathrm{F}=6.094 ; \mathrm{p}<.05)$, ve diğer $(\mathrm{F}=13.265 ; \mathrm{p}<.05)$ boyutlarından aldıkları puanlar arasında anlamlı bir ilişkinin olduğu görülmektedir. Katılımcıların not ortalamaları ile yeterlilik $(\mathrm{F}=.556 ; \mathrm{p}>.05)$, ve tanınma $(\mathrm{F}=1.215 ; \mathrm{p}>.05)$ boyutlarından aldıkları puanlar arasında anlamlı bir ilişkinin olmadığı görülmektedir. Yapılan çoklu Tukey testine göre not ortalaması 3.00-4.00 arasında olan öğretmen adayları, not ortalaması 0-2.50 arasında not ortalamasına sahip öğretmen adaylarına göre okumayı hayatının merkezine koymakta, arkadaşlarını şaşırtacak kadar kitap okumakta, okumaya vakit ayırmakta, okuyarak diğer insanlara örnek olmakta, okumanın hayatını daha anlamlı kıldığını belirtmekte ve hızlı okuduğunu düşünmektedir. Not ortalaması 3.00-4.00 arasında olan öğretmen adayları, not ortalaması $0-2.50$ ve 2.512.99 arasında not ortalamasına sahip öğretmen adaylarına göre ve not ortalaması 2.51-2.99 olan öğretmen adayları, 0-2.50 not ortalamasına sahip öğretmen adaylarına göre okumayı bir ihtiyaç olarak görmekte, performansı ve üniversitedeki aldığı notları okumaya bağlamakta, gerekli bütün okumaları yaptığını düşünmekte, performansını geliştirmek için okumanın önemli olduğuna inanmaktadır.

Tablo 24. Öğretmen Adaylarının Sınıf Düzeyleri ile Yetişkin Okuma Motivasyonu Boyutları Arasındaki ANOVA Analizleri

\begin{tabular}{|c|c|c|c|c|c|c|c|}
\hline Değişken & $\begin{array}{l}\text { Varyansın } \\
\text { Kaynağ } 1\end{array}$ & $\begin{array}{l}\text { Kareler } \\
\text { Toplami }\end{array}$ & sd & $\begin{array}{c}\text { Kareler } \\
\text { Ortalamas1 }\end{array}$ & $\mathrm{F}$ & $\mathrm{p}$ & $\begin{array}{l}\text { Anlaml1 } \\
\text { Farkl111k }\end{array}$ \\
\hline \multirow{3}{*}{ Benlik } & Gruplar arası & 3,687 & 3 & 1,229 & 2,391 & ,040 & C-D \\
\hline & Gruplar içi & 105,390 & 205 &, 514 & & & \\
\hline & Toplam & 109,077 & 208 & & & & \\
\hline \multirow{3}{*}{ Yeterlilik } & Gruplar aras & 2,676 & 3 & ,892 & 1,457 & 227 & \\
\hline & Gruplar içi & 125,476 & 205 & ,612 & & & \\
\hline & $\begin{array}{l}\text { Toplam } \\
\text { Grunlar }\end{array}$ & $\begin{array}{c}128,152 \\
0,350\end{array}$ & 208 & 3117 & 2778 & 052 & \\
\hline \multirow[t]{2}{*}{ Tanınma } & Gruplar içi & 229,969 & 205 & 1,122 & & & \\
\hline & Toplam & 239,320 & 208 & & & & \\
\hline \multirow[b]{2}{*}{ Diğer } & Gruplar aras1 & 1,914 & 3 & 638 & ,973 & 406 & \\
\hline & Gruplar içi & 134,402 & 205 & ,656 & & & \\
\hline
\end{tabular}

A:1. sinif, B: 2.sinif, C: 3.sinif, D:4.sinif

Tablo 24 incelendiğinde katılımcıların sınıf düzeyleri ile benlik $(\mathrm{F}=2,391 ; \mathrm{p}<.05)$ boyutundan aldıkları puanlar arasında anlamlı bir ilişkinin olduğu görülmektedir. Katılımciların sınıf düzeyleri ile tanınma $(F=2,778 ; p>.05)$, yeterlilik $(F=1,457 ; p>.05)$, diğer $(\mathrm{F}=, 973 ; \mathrm{p}>.05)$ boyutlarından aldıkları puanlar arasında anlamlı bir ilişkinin olmadığı görülmektedir. Tukey testi sonuçlarına göre 3. sınıflar, 4. sınıflara göre okumaya vakit ayırmanın önemli olduğunu, okuyarak diğer insanlara örnek olabileceklerini, okuma olmasaydı hayatın anlamının olmayacağını, arkadaşlarını şaşırtacak kadar çok okuduklarını ve hızlı okuduklarını düşünmektedirler. 
Tablo 25. Öğretmen Adaylarının Kitap Okuma Sayıları ile Yetişkin Okuma Motivasyonu Boyutları Arasındaki ANOVA Analizleri

\begin{tabular}{|c|c|c|c|c|c|c|c|}
\hline Değişken & $\begin{array}{c}\text { Varyansın } \\
\text { Kaynağ1 }\end{array}$ & $\begin{array}{l}\text { Kareler } \\
\text { Toplamı }\end{array}$ & sd & $\begin{array}{c}\text { Kareler } \\
\text { Ortalamas } 1\end{array}$ & $\mathrm{~F}$ & $\mathrm{p}$ & $\begin{array}{l}\text { Anlamlı } \\
\text { Farklılık }\end{array}$ \\
\hline \multirow{3}{*}{ Benlik } & Gruplar arası & 36,609 & 3 & 12,203 & 34,52 & ,000 & C-D \\
\hline & Gruplar içi & 72,468 & 205 & ,354 & & & \\
\hline & Toplam & 109,077 & 208 & & & & \\
\hline \multirow{3}{*}{ Yeterlilik } & Gruplar arası & 24,779 & 3 & 8,260 & 16,38 &, 000 & D-A \\
\hline & Gruplar içi & 103,373 & 205 & ,504 & & & C-B \\
\hline & Toplam & 128,152 & 208 & & & & \\
\hline \multirow{3}{*}{ Tanınma } & Gruplar arası & 8,335 & 3 & 2,778 & 2,46 & ,063 & \\
\hline & Gruplar içi & 230,985 & 205 & 1,127 & & & \\
\hline & Toplam & 239,320 & 208 & & & & \\
\hline \multirow{3}{*}{ Diğger } & Gruplar arası & 11,513 & 3 & 3,838 & 6,30 &, 000 & D-A \\
\hline & Gruplar içi & 124,804 & 205 & 609 & & & $\mathrm{C}-\mathrm{A}$ \\
\hline & Toplam & 136,316 & 208 & & & & B-A \\
\hline
\end{tabular}

A:0-5 B: 6-10 C: 11-15 D:16 ve üzeri

Tablo 25 incelendiğinde öğretmen adaylarının kitap okuma sayıları ile benlik $(\mathrm{F}=34,52 ; \mathrm{p}<.05)$, yeterlilik $(\mathrm{F}=16,38 ; \mathrm{p}<.05)$, diğer $(\mathrm{F}=6,30 ; \mathrm{p}<.05)$ boyutlarından aldıkları puanlar arasında anlamlı bir ilişkinin olduğu görülmektedir. Katılımcıların kitap okuma sayıları ile tanınma $(\mathrm{F}=2,46 ; \mathrm{p}>.05)$ boyutundan aldıkları puanlar arasında anlamlı bir ilişkinin olmadığı görülmektedir. Tukey karşılaştırma testine göre 11-15 arası kitap okuyan öğretmen adayları 16 ve üzeri kitap okuyan öğretmen adaylarına göre okumaya vakit ayırmanın önemli olduğunu, okuyarak diğer insanlara örnek olabileceklerini, okuma olmasaydı hayatın anlamının olmayacağını, arkadaşlarını şaşırtacak kadar çok okuduklarını ve hızlı okuduklarını düşünmektedirler. 16 ve üzeri kitap okuyan öğretmen adaylarının 0-5 arası kitap okuyanlara göre ve 11-15 arası kitap okuyan öğretmen adaylarının 6-10 arası kitap okuyanlara göre ilgi makaleleri ve kitapları zor olsa da anlayarak okuyabildiklerini, zor düşündürücü kitap ve makaleleri sevdiklerini ve iyi bir okuyucu olduklarını ifade etmektedirler. 16 ve üzeri, 11-15 arası ve 6-10 arası kitap okuyan öğretmen adayları, 0-5 arası kitap okuyanlara göre bir ihtiyaç halinde zamanından önce okuyup bitirdiklerini, iş hayatında ve üniversitede aldıkları notların okuma etkililiğinin bir göstergesi olduğunu, işi veya üniversitedeki dersleri için tüm okumaları tamamladıklarını, iş veya üniversite performansını geliştirmek için okuduklarını ifade etmektedirler.

Tablo 26. Öğretmen Adaylarının İnternette Geçirdikleri Süre ile Yetişkin Okuma Motivasyonu Boyutları Arasındaki ANOVA Analizleri

\begin{tabular}{lccccccc}
\hline \multicolumn{1}{c}{ Değişken } & $\begin{array}{c}\text { Varyansın } \\
\text { Kaynăg }\end{array}$ & $\begin{array}{c}\text { Kareler } \\
\text { Toplamı }\end{array}$ & sd & $\begin{array}{c}\text { Kareler } \\
\text { Ortalaması }\end{array}$ & F & P & $\begin{array}{c}\text { Anlamlı } \\
\text { Farklılık }\end{array}$ \\
\hline İşim veya üniversitedeki & Gruplar arasi & 12,983 & 3 & 4,328 & 4,240 &, 006 & B-C \\
derslerim için gerekli tüm & Gruplar içi & 209,237 & 205 & 1,021 & & & \\
okumaları tamamlarım. & Toplam & 222,220 & 208 & & & & \\
& Gruplar arası & 7,661 & 3 & 2,554 & 2,848 &, 039 & B-C \\
Iyji bir okuyucuyumdur. & Gruplar içi & 183,793 & 205 &, 897 & & & \\
& Toplam & 191,455 & 208 & & & & \\
\hline
\end{tabular}

$A: 0-1, B: 2-3, C: 4-6, D: 7$ ve üzeri 
Tablo 26 incelendiğinde öğretmen adaylarının internette geçirdikleri süre ile tabloda yer alan maddeler maddelerden aldıkları puanlar arasında anlamlı bir ilişkinin olduğu görülmektedir. Tukey karşılaştırma testi sonuçlarına göre 2-3 saat arası internette vakit geçiren öğretmen adayları, 4-6 saat internette vakit geçiren öğretmen adaylarına göre kendilerini iyi bir okuyucu olarak görmekte, ihtiyaçları için gerekli olan tüm okumaları tamamladıklarını belirtmektedirler.

Tablo 27. Öğretmen Adaylarının Kitap Okuma Amaçları ile Yetişkin Okuma Motivasyonu Boyutları Arasındaki ANOVA Analizleri

\begin{tabular}{|c|c|c|c|c|c|c|c|}
\hline Değişken & $\begin{array}{c}\text { Varyansin } \\
\text { Kaynağ1 }\end{array}$ & $\begin{array}{l}\text { Kareler } \\
\text { Toplamı }\end{array}$ & sd & $\begin{array}{c}\text { Kareler } \\
\text { Ortalamas1 }\end{array}$ & $\mathrm{F}$ & $\mathrm{p}$ & $\begin{array}{c}\text { Anlamlı } \\
\text { Farklılık }\end{array}$ \\
\hline \multirow{3}{*}{ Benlik } & Gruplar arası & 14,625 & 5 & 2,925 & 6,287 &, 000 & C-A, C-B \\
\hline & Gruplar içi & 94,452 & 203 & ,465 & & & C-F, D-B \\
\hline & Toplam & 109,077 & 208 & & & & D-F \\
\hline \multirow{3}{*}{ Yeterlilik } & Gruplar arası & 12,077 & 5 & 2,415 & 4,224 & 001 & \\
\hline & Gruplar içi & 116,075 & 203 &, 572 & & & \\
\hline & Toplam & 128,152 & 208 & & & & \\
\hline \multirow{3}{*}{ Tanınma } & Gruplar aras1 & 3,602 & 5 & ,720 & 620 & 684 & \\
\hline & Gruplar içi & 235,718 & 203 & 1,161 & & & \\
\hline & Toplam & 239,320 & 208 & & & & \\
\hline \multirow{3}{*}{ Diğer } & Gruplar aras1 & 8,605 & 5 & 1,721 & 2,736 &, 020 & \\
\hline & Gruplar içi & 127,711 & 203 & 629 & & & \\
\hline & Toplam & 136,316 & 208 & & & & \\
\hline
\end{tabular}

A: Bilgi sahibi olmak ve merak duygusunu gidermek için, B: Boş zamanı değerlendirmek ve verimli zaman geçirmek için, C: Bakış açısını ve hayal dünyasını genişletmek için, D: Söz dağarcı̆̆ını ve diksiyonu geliştirmek için, E: Keyifli zaman geçirmek için, F: Diğer

Tablo 28 incelendiğinde öğretmen adaylarının kitap okuma amaçları ile benlik $(\mathrm{F}=6.287 ; \mathrm{p}<.05)$, yeterlilik $(\mathrm{F}=4.224 ; \mathrm{p}<.05)$, diğer $(\mathrm{F}=2.736 ; \mathrm{p}<.05)$ boyutlarından aldıkları puanlar arasında istatistiksel olarak anlamlı bir farklılığın olduğu görülmektedir. Öğretmen adaylarının kitap okuma amaçları ile tanınma $(\mathrm{F}=.620 ;>05)$ boyutundan aldıkları puanlar arasında anlamlı bir farklılığın olmadığı görülmektedir. Tukey testi sonucuna göre bakış açısını ve hayal dünyasını genişletmek için kitap okuyan öğretmen adayları, bilgi sahibi olmak ve merak duygusunu gidermek için, boş zamanı değerlendirmek ve verimli zaman geçirmek için ve diğer grubunda yer alan öğretmen adaylarına göre; söz dağarcığını ve diksiyonu geliştirmek için kitap okuyan öğretmen adayları, boş zamanı değerlendirmek ve verimli zaman geçirmek için okuyan ve diğer grubunda yer alan öğretmen adaylarına göre kitap okumayı hayatın merkezine koymakta, kitap okumaya daha fazla vakit ayırmakta, örnek kitap okuyucu durumuna gelmek istemektedirler.

\section{Sosyal Medyaya Özgü Epistemolojik İnançlar Ölçeği Analizleri}

Tablo 28. Sosyal Medya Tabanlı Bilginin Basitliği ve Kesinliği Boyutuna Ait Tanımlayıcı İstatistik Analizleri

\begin{tabular}{|c|c|c|c|c|}
\hline $\begin{array}{l}\text { Boyut } \\
\text { Ad1 }\end{array}$ & Maddeler & $\overline{\mathbf{x}}$ & SS & $\begin{array}{l}\text { Genel } \\
\text { Ortalama }\end{array}$ \\
\hline \multirow{4}{*}{ 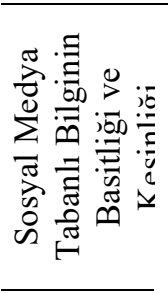 } & Sosyal medyada doğru olarak kabul edilip, beğenilip, paylaşılan bir & 4,35 & 0,84 & \multirow{4}{*}{2,94} \\
\hline & $\begin{array}{l}\text { Sosyal medyada tartışılan bir problemin birden çok doğru cevabı } \\
\text { vardır. }\end{array}$ & 3,75 & 1,02 & \\
\hline & $\begin{array}{l}\text { Sosyal medyada bir konudaki detay, o konu ile ilgili diğer } \\
\text { bilgilerden daha önemlidir. }\end{array}$ & 2,94 & 1,2 & \\
\hline & Sosyal medyada paylaşılan bir bilginin doğruluğunun ve & 1,85 & 1,21 & \\
\hline
\end{tabular}


geçerliliğinin zamanla değişebileceğini düşünmem.

Sosyal medyadaki belli bir alana ait bilgiler değișmez ve kesindir.

$1,81 \quad 1,15$

Tablo 28 incelendiğinde öğretmen adayları sosyal medyadaki bilgilerin zamanla değişebileceğini, sosyal medyada tartışılan bir durumun zamanla değişebileceğini ifade etmektedir.

Tablo 29. Bilginin Kaynağı Boyutuna Ait Tanımlayıcı İstatistik Analizleri

\begin{tabular}{|c|c|c|c|c|}
\hline $\begin{array}{l}\text { Boyut } \\
\text { Ad1 }\end{array}$ & Maddeler & $\overline{\mathrm{x}}$ & Ss & $\begin{array}{c}\text { Genel } \\
\text { Ortalama }\end{array}$ \\
\hline \multirow{5}{*}{ 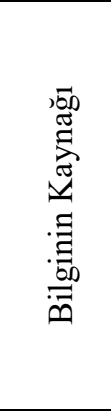 } & $\begin{array}{l}\text { Belli bir alanda uzman kişi tarafindan paylaşılsa bile, sosyal } \\
\text { medvada gördüŏöm biloive elestirel vaklasırım. }\end{array}$ & 3,99 & 0,85 & \multirow{5}{*}{2,84} \\
\hline & $\begin{array}{l}\text { Sosyal medya hesabını takip ettiğim uzman kişinin paylaşmış olduğu } \\
\text { bilgi, kişisel tecrübelerimle uyuşmasa bile, daha güvenilirdir. }\end{array}$ & 2,85 & 1,11 & \\
\hline & $\begin{array}{l}\text { Bir uzmanın sosyal medyada paylaştı̆̆ bilgiyi kendi hesabımda } \\
\text { paylaşırken kendimi daha güvenilir hissederim. }\end{array}$ & 2,74 & 1,22 & \\
\hline & $\begin{array}{l}\text { Herhangi bir uzmanın sosyal medyada paylaştığı bilgiyi, kendi } \\
\text { hesabımda paylaşmak için tereddüt etmem. }\end{array}$ & 2,55 & 1,13 & \\
\hline & $\begin{array}{l}\text { Sosyal medyada daha fazla takipçisi olan bir kişinin paylaştığ bir } \\
\text { alandaki bilgi, benim için daha güvenilirdir. }\end{array}$ & 2,05 & 1,22 & \\
\hline
\end{tabular}

Tablo 29 incelendiğinde öğretmen adaylarının sosyal medyadaki bilgilere eleştirel yaklaştıkları, sosyal medyadaki uzmanların paylaşımlarına genel olarak güvendiklerini, sosyal medyadaki diğer bireylerin paylaşımlarını çok güvenilir bulmadıklarını ifade etmektedirler.

Tablo 30. Bilmenin Kanıtı Boyutuna Ait Tanımlayıcı İstatistik Analizleri

\begin{tabular}{|c|c|c|c|c|}
\hline $\begin{array}{c}\text { Boyut } \\
\text { Ad1 }\end{array}$ & Maddeler & $\overline{\mathrm{x}}$ & ss & $\begin{array}{l}\text { Genel } \\
\text { Ortalama }\end{array}$ \\
\hline \multirow{5}{*}{ 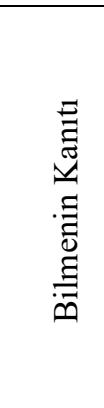 } & $\begin{array}{l}\text { Sosyal medyada birçok kişinin beğenip paylaşmış olduğu bilgi, } \\
\text { benim için o bilginin doğru olduğu anlamına gelmez. }\end{array}$ & 4,28 & 1,02 & \multirow{5}{*}{4,09} \\
\hline & $\begin{array}{l}\text { Sosyal medyada gördüğüm bilginin güvenilir olup olmadığını daha } \\
\text { önce edindiğim bilgilerle ilişkilendirerek değerlendiririm. }\end{array}$ & 4,08 & 0,84 & \\
\hline & $\begin{array}{l}\text { Sosyal medyada paylaşlan bir bilgi için hislerim o bilginin doğru } \\
\text { olduğunu söylese bile, başka kaynakları da incelerim. }\end{array}$ & 4,07 & 0,98 & \\
\hline & $\begin{array}{l}\text { Sosyal medyada okuduğum bir bilginin mantıklı olup olmadığını } \\
\text { farklı internet sitelerinden araştırırım. }\end{array}$ & 4,06 & 0,97 & \\
\hline & $\begin{array}{l}\text { Sosyal medyada karşıllaştığım bilgiyi kendi hesabımda paylaşmadan } \\
\text { önce farklı kaynaklardan kontrol ederim. }\end{array}$ & 3,94 & 1,03 & \\
\hline
\end{tabular}

Tablo 30 incelendiğinde öğretmen adaylarının sosyal medyada paylaşılan bilginin güvenilir olup olmaması hakkında kanıtlara ihtiyaç duyduklarını ifade etmektedirler.

Tablo 31. Öğretmen Adaylarının Kardeş Sayıları ile Sosyal Medyaya Özgü Maddeler Arasındaki ANOVA Analizleri

\begin{tabular}{|c|c|c|c|c|c|c|c|}
\hline Değişken & $\begin{array}{c}\text { Varyansın } \\
\text { Kaynağ1 }\end{array}$ & $\begin{array}{l}\text { Kareler } \\
\text { Toplam1 }\end{array}$ & $\mathrm{sd}$ & $\begin{array}{c}\text { Kareler } \\
\text { Ortalamas1 }\end{array}$ & $\mathrm{F}$ & $\mathrm{p}$ & $\begin{array}{l}\text { Anlaml1 } \\
\text { Farklılık }\end{array}$ \\
\hline $\begin{array}{l}\text { Herhangi bir uzmanın sosyal } \\
\text { medyada paylaştığı bilgiyi, }\end{array}$ & $\begin{array}{l}\text { Gruplar } \\
\text { aras1 }\end{array}$ & 11,105 & 3 & 3,702 & 2,958 & ,033 & B-A \\
\hline $\begin{array}{l}\text { kendi hesabımda paylaşmak için } \\
\text { tereddüt etmem. }\end{array}$ & $\begin{array}{l}\text { Gruplar içi } \\
\text { Toplam }\end{array}$ & $\begin{array}{l}256,512 \\
267,617\end{array}$ & $\begin{array}{l}205 \\
208\end{array}$ & 1,251 & & & \\
\hline $\begin{array}{l}\text { Sosyal medyada gördüğüm } \\
\text { bilginin güvenilir olup }\end{array}$ & $\begin{array}{c}\text { Gruplar } \\
\text { aras1 }\end{array}$ & 5,555 & 3 & 1,852 & 2,656 & ,050 & D-A \\
\hline olmadığını daha önce edindiğim & Gruplar içi & 142,895 & 205 & ,697 & & & \\
\hline $\begin{array}{l}\text { bilgilerle ilişkilendirerek } \\
\text { değerlendiririm. }\end{array}$ & Toplam & 148,450 & 208 & & & & \\
\hline $\begin{array}{l}\text { Sosyal medyada okuduğum bir } \\
\text { bilginin mantıklı olup }\end{array}$ & $\begin{array}{l}\text { Gruplar } \\
\text { aras1 }\end{array}$ & 8,276 & 3 & 2,759 & 2,964 & ,033 & D-A \\
\hline
\end{tabular}


olmadığını farklı internet $\quad$ Gruplar içi $\quad 190,786 \quad 205 \quad$,931

sitelerinden araştırırım.

Toplam $199,062 \quad 208$

$A: 1, B: 2 C: 3, D: 4$ ve üzeri

Tablo 31 incelendiğinde öğretmen adaylarının kardeş sayıları ile "Herhangi bir uzmanın sosyal medyada paylaştı̆̆ bilgiyi, kendi hesabımda paylaşmak için tereddüt etmem" (F=2,958; $\mathrm{p}<.05)$, "Sosyal medyada gördüğüm bilginin güvenilir olup olmadı̆̆ını daha önce edindiğim bilgilerle ilişkilendirerek değerlendiririm" $(\mathrm{F}=2,656 ; \mathrm{p}<.05)$, "Sosyal medyada okuduğum bir bilginin mantıklı olup olmadığını farklı internet sitelerinden araştırırım." ( $\mathrm{F}=2,964 ; \mathrm{p}<.05)$, maddelerinden aldıkları puanlar arasında anlamlı bir ilişkinin olduğu görülmektedir. Tukey karşılaştırma testi sonucuna göre 2 kardeş olan öğretmen adayları tek çocuk olan öğretmen adaylarına göre herhangi bir uzmanın sosyal medyada paylaştığı bilgiyi, kendi hesabında paylaşmak için tereddüt etmemektedir. 4 kardeş ve üzeri olan öğretmen adayları tek çocuk olan öğretmen adaylarına göre sosyal medyada gördükleri bilginin güvenilir olup olmadığını daha önce edindiği bilgilerle ilişkilendirip değerlendirmekte, sosyal medyada okudukları bir bilginin mantıklı olup olmadığını farklı internet sitelerinden araştırmaktadırlar.

Tablo 32. Öğretmen Adaylarının Sınıf Düzeyleri ile Sosyal Medyaya Özgü Boyutlar Arasındaki ANOVA Analizleri

\begin{tabular}{cccccccc}
\hline Değişken & $\begin{array}{c}\text { Varyansın } \\
\text { Kaynağı }\end{array}$ & $\begin{array}{c}\text { Kareler } \\
\text { Toplamı }\end{array}$ & sd & $\begin{array}{c}\text { Kareler } \\
\text { Ortalaması }\end{array}$ & F & p & $\begin{array}{c}\text { Anlamlı } \\
\text { Farklılık }\end{array}$ \\
\hline Sosyal Medya Tabanlı & Gruplar arası & 2,511 & 3 &, 837 & 1,874 &, 135 & \\
Bilginin Basitliği ve & Gruplar içi & 91,529 & 205 &, 446 & & & \\
Kesinliği & Toplam & 94,040 & 208 & & & & \\
& Gruplar arası & 6,727 & 3 & 2,242 & 4,351 &, 005 & B-D \\
Bilginin Kaynağı & Gruplar içi & 105,656 & 205 &, 515 & & & \\
& Toplam & 112,382 & 208 & & & \\
& Gruplar arası & 4,034 & 3 & 1,345 & 2,327 &, 076 \\
Bilmenin Kanıtı & Gruplar içi & 118,435 & 205 &, 578 & & & \\
& Toplam & 122,469 & 208 & & & & \\
\hline
\end{tabular}

A:1. sinif, B:2.sinif, C:3.sinif, D:4.sinif

Tablo 32 incelendiğinde öğretmen adaylarının sınıf düzeyleri ile sosyal medya tabanlı bilginin basitliği ve kesinliği $(\mathrm{F}=1,874 ; \mathrm{p}>.05)$, bilmenin kanıtı $(\mathrm{F}=2,327 ; \mathrm{p}>.05)$ boyutlarından aldıkları puanlar arasında anlamlı bir ilişkinin olmadığı görülmektedir. Katılımcıların sınıf düzeyleri ile bilginin kaynağı $(\mathrm{F}=4,351 ; \mathrm{p}<.05)$ boyutundan aldıkları puanlar arasında anlamlı bir ilişkinin olduğu görülmektedir. Tukey karşılaştırma sonucuna göre 2. sınıflar, 4. sınıflara göre sosyal medyada uzmanların paylaşımlarını daha güvenilir bulmaktadırlar.

Tablo 33. Öğretmen Adaylarının Kitap Okuma Sayıları ile Sosyal Medyaya Özgü Boyutlar Arasındaki ANOVA Analizleri

\begin{tabular}{cccccccc}
\hline Değişken & $\begin{array}{c}\text { Varyansın } \\
\text { Kaynağı }\end{array}$ & $\begin{array}{c}\text { Kareler } \\
\text { Toplamı }\end{array}$ & sd & $\begin{array}{c}\text { Kareler } \\
\text { Ortalaması }\end{array}$ & F & p & $\begin{array}{c}\text { Anlamlı } \\
\text { Farklılık }\end{array}$ \\
\hline Sosyal Medya Tabanlı & Gruplar arası &, 527 & 3 &, 176 &, 385 &, 764 & \\
Bilginin Basitliği ve & Gruplar içi & 93,513 & 205 &, 456 & & & \\
Kesinliği & Toplam & 94,040 & 208 & & & & \\
& Gruplar arası & 1,841 & 3 &, 614 & 1,138 &, 335 & \\
Bilginin Kaynağ1 & Gruplar içi & 110,541 & 205 &, 539 & & & \\
& Toplam & 112,382 & 208 & & & & D-A
\end{tabular}




\begin{tabular}{crrr}
\hline Gruplar içi & 117,034 & 205 & \multirow{2}{*}{, 571} \\
Toplam & 122,469 & 208 & \\
\hline
\end{tabular}

A:0-5, B:6-10, C:11-15, D:16 ve üzeri

Tablo 33 incelendiğinde öğretmen adaylarının kitap okuma sayıları ile sosyal medya tabanlı bilginin basitliği ve kesinliği $(F=, 385 ; \mathrm{p}>.05)$ ve bilginin kaynağ $(F=1,138$; p>.05) boyutlarından aldıkları puanlar arasında anlamlı bir ilişskinin olmadığı görülmektedir. Öğretmen adaylarının sınıf düzeyleri ile bilmenin kanıtı $(F=3,173 ; p<.05)$ boyutundan aldıkları puanlar arasında anlamlı bir ilişkinin olduğu görülmektedir. Tukey testi karşılaştırma sonucuna göre 16 ve üzeri kitap okuyan öğretmen adayları, 0-5 arası kitap okuyan öğretmen adaylarına göre sosyal medyada paylaşılan bilgilerin güvenirliğini sorgulamakta, farklı kaynaklardan bilginin doğru olup olmadığını kontrol etmektedir.

Tablo 34. Öğretmen Adaylarının Okuma Motivasyonları ile Sosyal Medyaya Özgü Epistemolojik İnançları Arasındaki İlişki

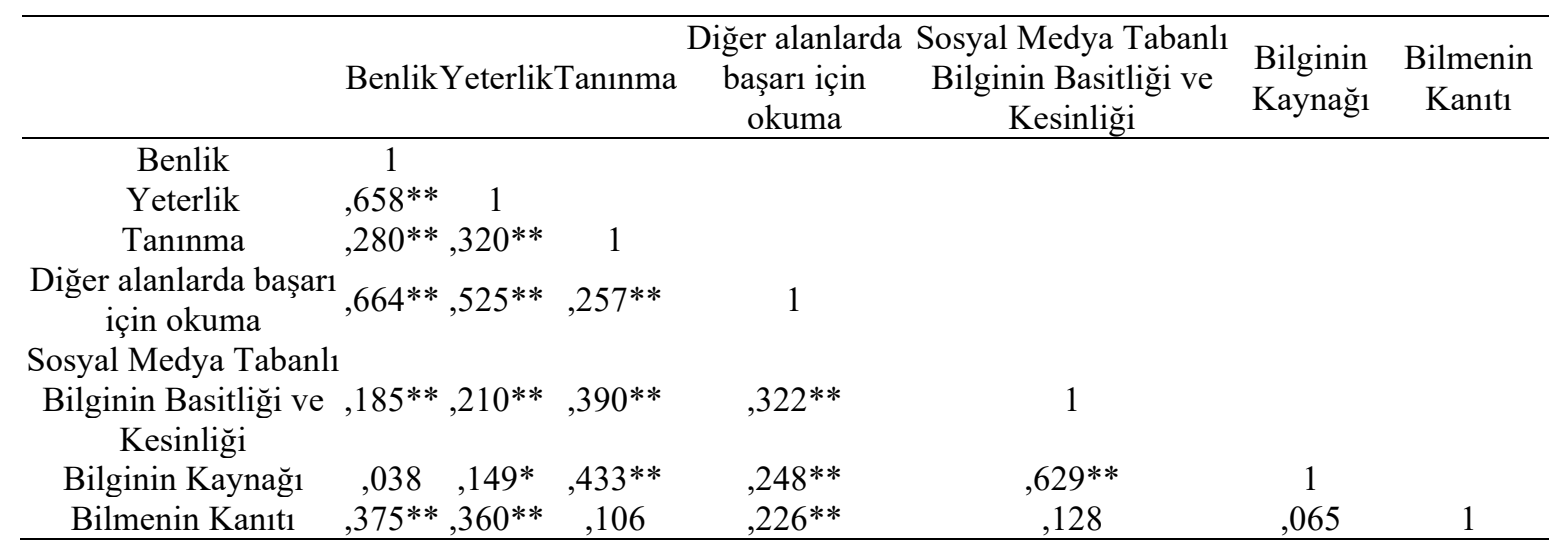

$* * \mathrm{p}<0.01$ anlamlılık seviyesinde ilişki anlamlı

Tablo 34 incelendiğinde, sosyal medya tabanlı bilginin basitliği ve kesinliği boyutuyla tanınma ve diğer alanlarda başarı için okuma boyutu arasında orta düzeyde pozitif yönde bir ilişkinin, aynı boyutla benlik ve yeterlik boyutu arasında düşük ve pozitif yönde bir ilişkinin olduğu görülmektedir. Katılımcıların sosyal medyada kullandıkları bilginin güvenilir olmasıyla kendi amaçları için okuma yapmaları ve tanınmak için okumaları arasında bir ilişkinin olduğu görülmektedir. Sosyal medyanın güvenirliğiyle kendilerini iyi bir okuyucu görmeleri ve okumayı hayatlarının merkezine koymaları arasında düşük düzeyde bir ilişkinin olduğu görülmektedir.

Bilginin kaynağı boyutuyla tanınma boyutu arasında orta düzeyde pozitif yönde bir ilişkinin; yeterlik ile diğer alanlarda başarı için okuma boyutu arasında düşük ve pozitif yönde bir ilişkinin olduğu görülmektedir. Bilginin kaynağı ile benlik boyutu arasında herhangi bir ilişkinin olmadığı görülmektedir. Sosyal medyada paylaşılan bilgilerin güvenli kaynaklar elde edilip paylaşılmasıyla okudukları hakkında yorum yapılması, övgü alınması durumları arasında orta düzey bir ilişkinin olduğu görülmektedir. Sosyal medyada paylaşılan bilgilerin güvenilir hesaplardan yapılmış olmasıyla kendisini iyi bir okuyucu olarak nitelendirme ve gerekli olduğu için okuma arasında düşük düzeyde bir ilişki bulunmaktadır. Sosyal medyada bilgileri güvenilir bir kaynaktan elde etmeyle okumanın hayatı anlamlı kılması arasında anlamlı bir ilişki bulunamamıştır.

Bilmenin kanıtı boyutuyla benlik ile yeterlik arasında pozitif yönde orta düzey bir ilişkinin olduğu; diğer alanlarda başarı için okuma arasında düşük düzeyde ve pozitif 
yönde bir ilişkinin olduğu görülmektedir. Tanınma ile bilmenin kanıtı boyutu arasında bir ilişkinin olmadığı görülmektedir. Sosyal medyadan elde edilen bilgileri başka bilgilerle eşleştirme ve kaynağını tespit etme ile okumanın hayatı anlamlı kılması ve iyi bir okuyucu olma arasında orta düzey bir ilişkinin olduğu, kendi çıkarları için okuma arasında düşük düzeyde bir ilişkinin olduğu görülmektedir.

\section{Sonuç ve Tartışma}

Araştırmaya katılan öğretmen adaylarının genel olarak bilgi sahibi olmak ve merak duygusunu gidermek, keyifli zaman geçirmek, bakış açısını değiştirmek, söz varlığını zenginleştirmek için kitap okudukları görülmektedir. Barata (2015) lise ve üniversite öğrencileriyle yaptığı araştırmasında öğrencilerin öğrenmek, alışkanlık, serbest zamanı değerlendirmek ve kişisel gelişim için okuduklarını tespit etmiştir. Yılmaz, Köse \& Korkut (2009) ders amaçlı, boş zamanları değerlendirme dinlenme ve gerçeklerden kaçış, bilgilendirme, hoşlanma, kişisel gelişim için okuduklarını belirlemiştir.

Araştırmaya katılan öğretmen adaylarının en çok basılı materyallerden kitap okudukları görülmektedir. Türkiye okuma kültürü araştırmasına (OKUYAY, 2019) göre Türkiye'de sosyal medya kullanan gençlerin okuma oranlarının arttığı, dünyada ise tam tersi bir gidişin görüldüğü tespit edilmiştir. Dağtaş'ın (2013) araştırmasında ise öğretmenlerin büyük bir çoğunluğu, genelde basılı metinlerden okumayı seçtiklerini belirtmiştir. Koçak, Yıldırım, Kurşun ve Yıldırım (2016) Açıköğretim Fakültesi öğrencileriyle yaptıkları araştırmasında öğrencilerin genellikle ders çalışırken taşınabilir ve her türlü ortamda okunabilir olması sebebiyle e-kitaptan okumayı seçtiklerini; bilgisayar ve tablet tercih ettiklerini tespit etmiştir. Baştuğ ve Keskin (2012) beşinci sınıfa devam eden öğrencilerle yaptığı araştırmasında öğrencilerin ekran okumadan ziyade kâğıttan okumada; anlama, doğruluk ve hız bakımından daha başarılı olduklarını belirtmiştir. Duran \& Topbaşoğlu'nun (2015) araştırmasında 4. sınıf öğrencileri tablet ve bilgisayara karşı kitaba göre daha olumlu bir tutum geliştirmişlerdir. Tüm bunlardan yola çıkarak, okuma yaşı küçüldükçe e-kitap, tablet, bilgisayar kullanımının arttığı, öğretmenlerin ve Türkçe öğretmeni adaylarının kitaptan okumayı tercih ettikleri söylenebilir.

Araştırmaya katılan öğretmen adaylarının okumak için belirli bir zaman dilimiyle kendilerini sınırlandırmadıkları görülmektedir. Bunun aksine Yılmaz (2009) araştırmasında Türkçe öğretmeni adaylarının akşam ve gece yarısı yatmadan önce okumayı tercih ettiklerini tespit etmiştir.

Araştırmaya katılan öğretmen adayları daha çok evde, yurtta, odada okumayı tercih etmektedirler. Bayat ve Çetinkaya (2018) araştırmaya katılan öğrencilerin büyük bir kısmının evde yatak odalarında okumayı seçtiklerini belirlemiştir. Okul ortamında ise fazla seçenek olmadığından öğrenciler sınıf ve kütüphanede okumaktadırlar. Öğrenciler kamusal alanda ise seyahat sırasında ve şehir kütüphanelerinde okumaktadırlar. Çoban, İleri \& Temir (2018) öğrencilerin yarısından fazlasının üniversite kütüphanesini hiç kullanmadıklarını veya çok nadir kullandıklarını, şehir kütüphanesini ise hiç kullanmadıklarını belirlemiştir.

Araştırmaya katılan öğretmen adayları okumayı hayatlarının merkezine koymakta ve okumanın hayatlarına anlam kattığını düşünmektedirler. Öğretmen adayları okumaya diğer etkinliklere göre daha çok önem vermektedirler. Araştırmaya katılan öğretmen 
adayları okuma konusunda kendilerini yeterli görmektedirler. İlgi çekici bir makaleyi okumanın zor olmadığını, iyi bir okuyucu olduklarını; zor, düşündürücü kitap ve makaleleri sevdiklerini ifade etmektedirler. Öğretmen adaylarının zor kitap ve makaleleri anlayabildiklerinden emin olmadıkları görülmektedir. Araştırmaya katılan öğretmen adayları tanınmak için okuduklarını, bu doğrultuda okuduklarıyla ilgili soru sorulmasının hoşlarına gittiğini, okudukları hakkında övgü almaya önem verdiklerini belirtmektedirler. Öğretmen adayları, diğer insanların, okudukları hakkında yorum yapmasını önemsememektedirler. Araştırmaya katılan öğretmen adayları ihtiyaç olan bilgileri kısa sürede okuyup bitirdiklerini, performanslarını geliştirmek için okuduklarını, aldığı notların okuma etkililiğinin bir göstergesi olduğunu düşündüklerini belirtmektedirler. Ülper \& Çeliktürk (2013), öğretmen adaylarının \%80'inin okuma güdüsünün yüksek olduğunu ifade etmiştir. Katrancı (2015) ilkokul 4. sınıf öğrencileri ile yaptığı çalışmada öğrencilerin kitap okuma motivasyonunun orta düzeyde olduğunu ifade etmiştir. Yılmaz \& Çalışkan (2017) ise yatılı ortaokul öğrencileri ile yaptıkları çalışmada öğrencilerin hem içsel hem de dışsal okuma motivasyonlarının yüksek olduğunu ifade etmişlerdir. Stutz, Schaffner ve Schiefele (2016), 2. ve 3. sınıf öğrencileriyle yaptıkları araştırmada dışsal motivasyon ile okuduğunu anlama becerileri arasında doğrudan ve olumsuz yönde ilişki tespit emişlerdir. Aynı araştırmada okumaya ayrılan süre ile okuduğunu anlama becerileri ve içsel okuma motivasyonu arasında pozitif yönde anlamlı ilişkiler olduğunu belirlemişlerdir.

Araştırmaya katılan kadın öğretmen adayları, erkek öğretmen adaylarına göre okumayı hayatın anlamı olarak görmektedirler. Yine kadın öğretmen adayları hoşlarına giden makale ya da kitapları arkadaşlarıyla değiş tokuş etmekte, okumaya vakit ayırmayı önemli bulmakta, okuyarak diğer insanlara karşı örnek olmaya çalışmakta ve hızlı okuduklarını belirtmektedirler. Kadın öğretmen adayları, erkek öğretmen adaylarına göre eğer okudukları materyal ihtiyaçsa bunları zamanından önce okumakta, performanslarının ve notlarının okuma etkililiğinin bir göstergesi olarak görmekte, işi ve üniversite için gerekli bütün okumaları yapmakta, performanslarını geliştirmek için okuduklarını belirtmektedirler. Bu çalışmaya benzer şekilde Batur, Gülveren ve Bek (2010) yaptığ araştırmada kadın öğrencilerin okuma alışkanlığının erkek öğrencilere göre daha yüksek seviyede olduğunu tespit etmiştir. Kuşdemir ve Bulut (2018) ilköğretim öğrencileri ile yaptığı çalışmada kız öğrencilerin okuma motivasyonunun erkek öğrencilerinkinden daha yüksek olduğunu ifade etmiştir. Araştırmalarda (Gömleksiz, 2005; Hassell \& Lutz, 2006; Smaragdi \& Jonsson, 2006; Korkmaz, 2007; Arslan, Çelik \& Çelik, 2009; Arslan, 2013) kadınların erkeklere oranla daha fazla okuduğu tespit edilmiştir.

Araştırmaya katılan ve yaşamlarının çoğunu büyükşehir, şehir ve kasabada geçiren öğretmen adayları, yaşamlarının çoğunu köyde geçiren öğretmen adaylarına göre "okuma olmasaydı hayatlarının aynı olmayacağını" düşünmektedirler. Araştırmaya katılan ve yaşamlarının çoğunu şehirde geçiren öğretmen adayları, yaşamlarının çoğunu büyükşehirde geçiren öğretmen adaylarına göre kendi yeterlik düzeylerini arttırmak için okuduklarını ifade etmektedirler. Bu sonuca benzer olarak Türkiye okuma kültürü araştırması (OKUYAY, 2019) raporunda “okuyanlar" kümesini oluşturanların ağırlıklı olarak genç, eğitimli ve metropolde yaşayan kişiler olduğu fakat kırda yaşayan, eğitimi düşük ve 49 yaş üstü bireylerin de hatırı sayılır bir oranda "okuyanlar" kümesinin içinde yer aldığg görülmektedir. Bu görüşün tersine Batur, Gülveren \& Bek (2010) öğrencilerin 
ilköğretimi ve ortaöğretimi köy, kasaba ya da şehirde tamamlamalarının okuma alışkanlığını doğrudan etkilemediğini söylemektedir. Çoban, İleri \& Temir'in (2018) araştırmaları gibi Batur, Gülveren \& Bek'in (2010) araştırmaları da kitap sayısı değişiklik gösterse de her yerleşim biriminde kütüphane bulunmasının okuma alışkanlığını geliştirmek için yeterli olduğunu göstermektedir.

Araştırmaya katılan öğretmen adaylarından babalarının meslekleri emekli, esnaf, işçi, serbest meslek, memur ve diğer olanlar, babalarının meslekleri çiftçi olanlara göre okumayı hayatlarının merkezlerine koymaktadırlar. Babalarının meslekleri esnaf olan öğretmen adaylarının babalarının meslekleri memur olanlara göre daha hızlı okudukları görülmektedir. Bu sonucun tersine, Yıldız \& Keskin (2016) araştırmasında anne baba mesleklerinin ergenlik dönemi öğrencilerinin dijital okuma düzeyleri üzerine etkisiyle ilgili anlamlı bir farklılık bulamazken Fidancı, Tekin, Uçkan, Arslan, Fidancı, Oğulluk, Aktürk ve diğerleri (2014) ise çalışmalarında baba mesleklerinin düzenli kitap okumayla birlikte ergenin iletişim, duygusal tepki verebilme, genel işlevsel fonksiyonları üzerinde etkili olduğu yönünde bu araştırmadaki sonuca paralel görüş belirtmiştir.

Araştırmaya katılan öğretmen adaylarından 4 ve üzeri kardeş olan öğretmen adayları, 2 kardeş olan öğretmen adaylarına göre kendilerini iyi okuyucu olarak görmekte, zor kitap ve makaleleri hem sevmekte hem de anlayabilmekte; ilgi çekiciliğin kitap ve makale okumada etkisi olduğunu düşünmektedirler. Bu sonuca paralel olarak Çoban, İleri ve Temir (2018) öğretmen adayları ile yaptığı çalışmada üç ve üzeri kardeşi olanların ailelerinde okumanın davranış niteliği kazanarak yaygın bir etkiye sahip olduğunu söylemektedir. Bu görüşlerin tersi doğrultusunda Batur, Gülveren ve Bek (2010) kardeş sayısı dikkate alındığında tek kardeş veya çok kardeşli olmanın öğrencilerin okuma alışkanlıklarında bir farklılık oluşturmadığını belirtmektedir.

Araştırmaya katılan öğretmen adaylarından babası ilkokul ve ortaokul mezunu olan katılımcılar, babası üniversite mezunu olan katılımcılara göre daha çok kitap okumakta ve arkadaşları bu duruma şaşırmaktadır. Babası ortaokul mezunu olan katılımcılar, babası ilkokul ve üniversite mezunu olan katılımcılara göre daha hızlı kitap okuduklarını ifade etmektedirler. Batur vd. (2010) araştırmasında öğrencilerin okuma alışkanlıklarıyla annebaba eğitim düzeyi arasında anlamlı fark olmadığını tespit etmiştir. Sadioğlu \& Bilgin (2008) ise çalışmasında çocukların eleştirel okuma düzeyleri ile anne baba eğitim durumu arasında anlamlı bir ilişki bulamamıştır.

Araştırmaya katılan öğretmen adaylarından not ortalaması diğer öğretmen adaylarına göre daha yüksek olanlar; okumayı hayatının merkezine koymakta, arkadaşlarını şaşırtacak kadar kitap okumakta, okumaya vakit ayırmakta, okuyarak diğer insanlara örnek olmakta, okumanın hayatını daha anlamlı kıldığını belirtmekte ve hızlı okuduğunu düşünmektedirler. Not ortalaması fazla olan öğretmen adayları not ortalaması biraz daha düşük olan öğretmen adaylarına göre daha fazla okumayı bir ihtiyaç olarak görmekte, performansı ve üniversitedeki aldığı notları okumaya bağlamakta, gerekli bütün okumaları yaptığını düşünmekte, performansını geliştirmek için okumanın önemli olduğuna inanmaktadır. Kurnaz ve Yıldız (2015) ortaokul öğrencileriyle yaptığ1 araştırmasında öğrencilerin Türkçe dersindeki akademik başarılarının okuma motivasyonunu arttırdığını ifade etmiştir. Yılmaz ve Çalışkan (2017) yatılı ortaokul öğrencileri ile yaptığı çalışmada sınıf düzeyinin okuma motivasyonunu etkilemediğini 
ifade etmektedir. Bıyık Ataş, Erdoğan ve Yıldız (2017) ise ilköğretim öğrencileri ile yaptıkları çalışmada öğrencilerin okuma motivasyonları ile sınıf düzeyleri arasında anlamlı farklılık olduğunu ifade etmişlerdir.

Araştırmaya katılan öğretmen adaylarından 3. sınıflar, 4. sınıflara göre okumaya vakit ayırmanın önemli olduğunu, okuyarak diğer insanlara örnek olabileceklerini, okuma olmasaydı hayatın anlamının olmayacağını, arkadaşlarını şaşırtacak kadar çok okuduklarını ve hızlı okuduklarını düşünmektedirler. Şahin (2019) Türkçe öğretmeni adaylarıyla yaptığ çalışmada sınıf düzeyinin okuma motivasyonları üzerinde anlamlı bir etkiye sahip olmadığını ifade etmiştir. Yıldız (2013) ilköğretim 3, 4 ve 5. sınıfta okuyan öğrencilerin okumaya yönelik içsel ve dışsal motivasyonlarını ölçmek için yaptığı çalışmada öğrencilerin okumaya yönelik motivasyonlarının yüksek olduğunu ama sınıf düzeyi arttıkça motivasyonun düştüğünü ifade etmektedir. Kurnaz ve Yıldız (2015) ise ortaokul öğrencileriyle yaptıkları çalışmada, 8. sınıfı hariç tutarak sınıf düzeyi arttıkça okuma motivasyonlarının azaldığını ifade etmişlerdir. Koçak, Çermik, Polat ve Şahin (2016) ise öğretmen adaylarının sınıf düzeyleri ile okumaya olan tutumları arasında anlamlı bir farkın olmadığını ifade etmişler ancak sıralamaya bakıldığında 1. sınıfta olan öğretmen adaylarının kitap okumaya olan tutum puanlarının en fazla, 4. sınıf öğrencilerinin ise en düşük olduğunu tespit etmişlerdir.

Araştırmaya katılan öğretmen adaylarından 11-15 arası kitap okuyan öğretmen adayları, 16 ve üzeri kitap okuyan öğretmen adaylarına göre okumaya vakit ayırmanın önemli olduğunu, okuyarak diğer insanlara örnek olabileceklerini, okuma olmasaydı hayatın anlamının olmayacağını, arkadaşlarını şaşırtacak kadar çok okuduklarını ve hızlı okuduklarını düşünmektedirler. Fazla kitap okuyan öğretmen adayları kendilerinden daha az kitap okuyan öğretmen adaylarına göre bir kitap ya da makale ilgi çekiciyse zor olsa da anlayarak okuduklarını, zor düşündürücü kitap ve makaleleri sevdiklerini ve iyi bir okuyucu olduklarını ifade etmektedirler. 0-5 arası kitap okuyanlardan daha fazla kitap okuyanlar, okumanın bir ihtiyaç olacaksa bunları zamanından önce okuyup bitirdiklerini, iş hayatında ve üniversitede aldıkları notların okuma etkililiğinin bir göstergesi olduğunu, iş veya üniversitedeki dersleri için tüm okumaları tamamladıklarını, iş veya üniversite performansını geliştirmek için okuduklarını ifade etmektedirler. Kurnaz ve Yıldız (2015) ortaokul öğrencileriyle yaptıkları çalışmada kitap okuma sayılarının arttıkça öğrencilerin okuma motivasyonlarının da artacağını ifade etmiştir. Şahin (2019) Türkçe öğretmeni adaylarının okuma motivasyonlarını incelemek için yaptığı çalışmada öğretmen adaylarının benlik, yeterlilik, diğer boyutlarında okunan kitap sayısı arttıkça okuma motivasyonun da artacağını; tanınma boyutunda ise okunan kitap sayısı arttıkça okuma motivasyonunun düşeceğini tespit etmiştir.

Araştırmada, 2-3 saat arası internette vakit geçiren öğretmen adayları, 4-6 saat internette vakit geçiren öğretmen adaylarına göre kendilerini iyi bir okuyucu olarak görmekte, ihtiyaçları için gerekli olan tüm okumaları tamamladıklarını belirtmektedirler. Kurnaz ve Yıldız (2015) ortaokul öğrencileri ile yaptıkları çalışmada, okuma motivasyonunu internet kullanım amaçlarından ödev ve bilgi için kullanan öğrencilerin; oyun-eğlence, film, sosyal medya için kullananlara göre daha yüksek olduğunu ancak bu farkın istatiksel olarak anlamlı olmadığını; bilgisayarın başında geçirilen günlük sürenin 
ise okuma motivasyonunu etkilediğini, özellikle bilgisayarda geçirilen sürenin günde 2-3 saat olmasının okuma motivasyonunu olumsuz etkilediğini ifade etmiştir.

Araştırmaya katılan öğretmen adaylarının çoğunun bilginin değişebileceğine inandıkları, paylaşılan bilgiye kime ait olursa olsun eleştirel yaklaştıkları, aynı zamanda sosyal medyada gördükleri bir bilginin birden çok kişi tarafından beğenilip paylaşılsa da doğruluğunu sorguladıkları söylenebilir. $\mathrm{Bu}$ bakımdan öğretmen adaylarının sosyal medyaya özgü epistemolojik inançlarının düşük olmadığı, aksine gelişmiş olduğu söylenebilir. Kanadlı ve Akbaş (2015) fen bilgisi öğretmen adayları ile yaptıkları çalışmada öğretmen adaylarının epistemolojik inançlarının gelişmiş aralıkta olduğunu ifade etmişlerdir. Eroğlu ve Güven (2006) ise öğretmen adayları ile yaptıkları çalışmada tek bir doğrunun var olduğuna dair inançlarının; öğrenmenin çabaya ve yeteneğe bağlı olduğu inanç boyutlarına kıyasla daha yüksek olduğunu tespit etmiştir. Bu çalışma yapılan çalışmanın sonuçları ile farklılık göstermektedir. Yenice vd. (2018) ise ortaöğretim öğrencileri ile yaptıkları çalışmada öğrencilerin bilimsel epistemolojik inançlarının genel olarak gelişmiş düzeyde olduğunu ifade etmektedir.

Araştırmaya katılan öğretmen adaylarından 2 kardeş olan öğretmen adayları tek çocuk olan öğretmen adaylarına göre herhangi bir uzmanın sosyal medyada paylaştı̆̆1 bilgiyi, kendi hesabında paylaşmakta tereddüt etmemektedir. 4 kardeş ve üzeri olan öğretmen adayları, tek çocuk olan öğretmen adaylarına göre sosyal medyada gördükleri bilginin güvenilir olup olmadığını daha önce edindiği bilgilerle ilişkilendirip değerlendirmekte, sosyal medyada okudukları bir bilginin mantıklı olup olmadığını farklı internet sitelerinden araştırmaktadır. Özel (2018) sosyal bilgiler öğretmen adayları ile yaptığı çalışmada az kardeşe sahip öğretmen adaylarının medya okuryazarlığına olan algılarının daha fazla kardeşi olan öğretmen adaylarına göre yüksek çıktığını tespit etmiştir.

Araştırmaya katılan öğretmen adaylarından 2. sınıf öğretmen adayları, 4. sınıf öğretmen adaylarına göre sosyal medya hesabını takip ettiği uzman kişinin paylaşmış olduğu bilgileri güvenilir bulmakta, bu bilgileri paylaşmakta bir sakınca görmemekte, daha fazla takipçisi olan bir kişinin paylaşımının daha güvenilir olduğunu düşünmektedir. Kalaman, Keklik ve Özkul (2019) ortaokul öğrencileriyle yaptıkları çalışmada öğrencilerin sınıf düzeyleri ile internete yönelik epistemolojik inançları arasında az bir düzeyde anlamlı farklılığın olduğunu ifade etmiştir. Başer Gülsoy, Erol ve Akbay (2015) ortaokul öğrencileri ile yaptıkları çalışmalarında öğrencilerin bilimsel epistemolojik inançları arasında 5. sınıfta okuyan öğrencilerin bilginin kesin ve doğru olduğuna ilişkin inançlarının 6. sınıfta okuyan öğrencilerden daha yüksek olduğunu ifade etmiştir. Faiz \& Karasu Avcı (2019) sosyal bilgiler öğretmen adayları ile yaptıkları çalışmada öğretmen adaylarının sınıf düzeyleri ile sosyal medyaya olan tutumları arasında bir ilişki olmadığını ifade etmiş ancak 1. sınıf öğrencilerinin 2. sınıf öğrencilerine göre sosyal medyaya daha düşkün olduklarını tespit etmiştir. Aypay (2011) ise sınıf düzeyi düşük olan öğrencilerin bilginin kesin ve değişmez olduğuna olan inançlarının sınıf düzeyi yüksek olan öğrencilerin bu konudaki inançlarından daha yüksek olduğunu belirlemiştir.

Araştırmaya katılan öğretmen adaylarından daha fazla kitap okuyanlar, sosyal medyada paylaşılan bilgilerin güvenirliğini sorgulamakta; farklı kaynaklardan bilginin doğru olup olmadığını kontrol etmektedirler. Faiz \& Karasu Avcı (2019), sosyal bilgiler 
öğretmen adayları ile yaptıkları çalışmada aylık okunan kitap sayısı ile sosyal medyaya olan tutumla ilgili; az kitap okuyan öğrencilerin sosyal medyaya ilgi boyutunda, fazla kitap okuyan öğrencilerin ise sosyal medyaya düşkünlük boyutunda tutumlarının olduğunu tespit etmiştir.

\section{Öneriler}

Pandemi sürecinde olduğu gibi e-kitap ve kaynak ulaşımları herkesin yararlanması için ücretsiz hale getirilebilir ya da bununla ilgili bir düzenlemeye gidilebilir.

Sosyal medya kullanıcılarının bilginin doğruluğunu sorgulamaları için kamu spotları oluşturulabilir. Bu sorgulamayı nasıl yapacaklarına ilişkin bilgilendirme videoları çekilebilir, kısa yazılar yayınlanabilir.

Bütün topluma uygun, teknolojiyi dikkate alarak uygun okuma ortamları oluşturmalıdır.

\section{Kaynakça}

Aktaş, E. \& Bayram, B. (2018). Türkçe öğretiminde okuduğunu anlama stratejilerinin kullanımı üzerine bir inceleme. Atatürk Üniversitesi Sosyal Bilimler Enstitüsü Dergisi, 22(3). 14011414. Retrieved from https://dergipark.org.tr/tr/pub/ataunisosbil/issue/39594/335730. (Erişim Tarihi: 20.04.2020)

Akyazı, E. \& Ünal, A. T. (2013). İletişim fakültesi öğrencilerinin amaç, benimseme, yalnızlık düzeyi ilişkisi bağlamında sosyal ağları kullanımı. Global Media Journal Turkish Edition, $3(6)$.

$1-24$.

https:/globalmediajournaltr.yeditepe.edu.tr/sites/default/files/Erhan\%20AKYAZI\%20-

\%20Aylin\%20TUTGUN\%20U\%CC\%88NAL.pdf (Erişim tarihi:15.05.2020).

Arslan, A. (2013). Okuma becerisi ile ilgili makalelerde cinsiyet değişkeni. Uluslararası Türkçe Edebiyat Kültür Eğitim (TEKE) Dergisi, 2(2), 251-265. DOI: 10.7884/teke.153.

Arslan, Y., Çelik, Z. \& Çelik, E. (2009). Üniversite Öğrencilerinin Okuma Alışkanlığına Yönelik Tutumlarının Belirlenmesi. PÜ Eğitim Fakültesi Dergisi, 26, 113-124.

Aydın, İ. E. (2016). Üniversite öğrencilerinin sosyal medya kullanımları üzerine bir araştırma: Anadolu üniversitesi örneği. Selçuk Üniversitesi Sosyal Bilimler Enstitüsü Dergisi, (35), 373-386. http://dergisosyalbil.selcuk.edu.tr/susbed/article/view/1256 (Erişim tarihi: 15.05.2020).

Aypay, A. (2011). Epistemolojik inançlar ölçeğinin Türkiye uyarlaması ve öğretmen adaylarının epistemolojik inançlarının incelenmesi. Eskişehir Osmangazi Üniversitesi Sosyal Bilimler Dergisi.

$12(1), 1-15$.

https://pdfs.semanticscholar.org/07ac/364d1f6cf4fb5602d509db7a58385d1b2d45.pdf (Erişim tarihi: 16.05.2020).

Balcı, Ş. \& Ayhan, B. (2007). Üniversite öğrencilerinin internet kullanım ve doyumları üzerine bir saha araştırması. Selçuk Üniversitesi Illetişim Fakültesi Dergisi, 5 (1), 174-197. Retrieved from https://dergipark.org.tr/tr/pub/josc/issue/19015/200730 (Erişim tarihi: 16.05.2020).

Barata, B. (2015). Gençlik hizmetleri ve spor il müdürlüklerine bağll gençlik merkezlerinin 15-29 yaş arasındaki gençler tarafindan bilinirlik düzeyi (Yayımlanmamış yüksek lisans tezi). Fırat Üniversitesi/Sağlık Bilimleri Enstitüsü, Elâzığ.

Başbay, M. (2013). Epistemolojik inancın eleştirel düşünme ve üstbiliş ile ilişkisinin yapısal eşitlik modeli ile incelenmesi. Eğitim ve Bilim Dergisi. 38(169). http://egitimvebilim.ted.org.tr/index.php/EB/article/view/2033/512. (Erişim tarihi:16.05.2020). 
Başer Gülsoy, V. G., Erol, O. \& Akbay, T. (2015). Ortaokul öğrencilerinin bilimsel epistemolojik inançlarının farklı değişkenlere göre incelenmesi. Mehmet Akif Ersoy Üniversitesi Eğitim Fakültesi Dergisi, 1(35), 1-28. Retrieved from https://dergipark.org.tr/tr/pub/maeuefd/issue/19408/206386 (Erişim Tarihi: 20.04.2020).

Baştuğ, M. \& Keskin, H. (2012). Okuma becerilerinin okuma ortamı açısından karşılaştırılması: Ekran mı kâğıt mı? Atatürk Üniversitesi Sosyal Bilimler Enstitüsü Dergisi, 16(3), 73-83. Retrieved from https://dergipark.org.tr/tr/pub/ataunisosbil/issue/2831/38447. (Erişim Tarihi: 20.04.2020).

Batur, Z., Gülveren, H. \& Bek, H. (2010). Öğretmen adaylarının okuma alışkanlıkları üzerine bir araştırma: uşak eğitim fakültesi örneği. Uşak Üniversitesi Sosyal Bilimler Dergisi, 3 (1), 32-49. Retrieved from https://dergipark.org.tr/tr/pub/usaksosbil/issue/21651/232769. (Erişim Tarihi: 20.04.2020)

Bayat, N. \& Çetinkaya, G. (2018). Ortaokul öğrencilerinin okuma alışkanlıkları ve tercihleri. Elementary Education Online, 17(2), 984-1001. DOI: 10.17051/ilkonline.2018.419349. (Erişim Tarihi: 20.04.2020)

Bıyık Ataş M., Erdoğan, T. \& Yıldız, M. (2017). The examining reading motivation of primary students in the terms of some variables. International Journal of Progressive Education. 13(3), 31-49. https://files.eric.ed.gov/fulltext/EJ1159916.pdf (Erişim tarihi:16.05.2020).

Büyüköztürk, Ş., Kılıç Çakmak, E., Akgün, Ö. E., Karadeniz, Ş. \& Demirel, F. (2018). Bilimsel araştırma yöntemleri. Ankara: Pegem Akademi Yayıncılık.

Çelik, İ. (2019). Social media-specific epistemological beliefs: A scale development study. Journal of Educational Computing Research. 58(2) 1-24. DOI:10.1177/0735633119850708.

Çoban, A., İleri, T. \& Temir, M. (2018). Üniversite öğrencilerinin kitap okuma alışkanlığına betimsel bir bakış: Amasya Üniversitesi örneği. Sosyal Bilimler Dergisi, 5(19), 50-69. https://www.researchgate.net/publication/322820396 (Erişim tarihi: 16.05.2020).

Dağtaş, A. (2013). Öğretmenlerin basılı sayfa ve ekrandan okuma tercihleri ile eğitimde elektronik metin kullanımına yönelik görüşleri. Turkish Studies, 8(3), 137-161. DOI: http://dx.doi.org/10.7827/TurkishStudies.4390.

Demir, M. K. (2012). İlköğretim bölümü öğretmen adaylarının epistemolojik inançlarının incelenmesi. Eğitim Fakültesi Dergisi. 25(2), 343-358. Retrieved from https://dergipark.org.tr/tr/pub/uefad/issue/16696/173555. (Erişim Tarihi: 20.04.2020)

Deryakulu, D. (2002). Denetim odağı ve epistemolojik inançların öğretim materyalini kavramay1 denetleme türü ve düzeyi ile ilişkisi. Hacettepe Üniversitesi Ĕ̆itim Fakültesi Dergisi, 22, 55-61. Retrieved from https://dergipark.org.tr/tr/pub/hunefd/issue/7814/102600. (Erişim Tarihi: 20.04.2020)

Deryakulu, D. \& Büyüköztürk, Ş. (2005). Epistemolojik inanç ölçeğinin faktör yapısının yeniden incelenmesi: cinsiyet ve öğrenim görülen program türüne göre epistemolojik inançların karş1laştırılması. Eğitim Araştırmaları Dergisi, $18, \quad$ 57-70. https://www.researchgate.net/profile/Deniz_Deryakulu2/publication/285660584 (Erişim tarihi: 16.05.2020).

Duran, E. \& Topbaşoğlu, N. (2015). Dijital-etkileşimli öyküleyici metinler ve anlama. Turkish Studies, 10(11), 519-532. DOI: http://dx.doi.org/10.7827/TurkishStudies.8550.

Eroğlu, S. E. \& Güven, K. (2006). Üniversite öğrencilerinin epistemolojik inançlarının bazı değişkenler açısından incelenmesi. Selçuk Üniversitesi Sosyal Bilimler Enstitüsü Dergisi, 16, 295-312. http://dergisosyalbil.selcuk.edu.tr/susbed/article/view/529/509 (Erişim tarihi: 16.05.2020).

Esmer, B. (2019). Okuduğunu anlama ile akıcı okuma, okur benlik algısl, okumaya adanmışlık ve okuyucu tepkisi ilişskileri. Gazi Üniversitesi, Eğitim Bilimleri Enstitüsü, Ankara. 
Faiz, M. \& Karasu-Avc1, E. (2019). Sosyal bilgiler öğretmen adaylarının sosyal medyaya yönelik tutumları. Uluslararası Sosyal Bilgilerde Yeni Yaklaşımlar Dergisi, 3(2), 146-166. Retrieved from https://dergipark.org.tr/tr/pub/sbyy/issue/51418/645801. (Erişim Tarihi: 20.04.2020)

Fidanc1, A., Tekin, O., Uçkan M. Ü., Arslan, İ., Fidancı, İ., Oğulluk, M., Aktürk, Oğulluk, Z., Cirit, E., Gümüş, E. \& Dilber S. (2014). Ergen gruplarında baba mesleklerine göre aile fonksiyonlarının gözlenmesi. 8. Aile Hekimliği Güz Okulu. (24-28 Eylül 2014). file://C:/Users/COMU/Downloads/aslhanfidanc\%20(1).pdf Erişim Tarihi: 16.05.2020.

Govani, T. \& Pashley H. (2007). Student awareness of the privacy implications when using facebook.

http://citeseerx.ist.psu.edu/viewdoc/download?doi=10.1.1.95.6108\&rep=rep1\&type=pdf.

(Erişim tarihi:02.05.2020).

Gömleksiz, M. N. (2005). Geleceğin öğretmenlerinin kitap okumaya ilişkin görüşlerinin değerlendirilmesi (Frrat üniversitesi eğitim fakültesi örneği). Yüzüncü Yll Üniversitesi, Elektronik Ĕ̈itim Fakültesi Dergisi. 1(1), 1-21.

Gündüz, O. \& Şimşek, T. (2011). Anlama Teknikleri-1 Uygulamalı Okuma Eğitimi El Kitabı. Ankara: Grafiker Yayınları.

Güneş, F. (2009). Hızlı okuma ve anlamı yapılandırma. Ankara: Nobel Yayıncılık.

Hassell, S. H. \& Lutz, C. (2006). A survey of the habits and attitudes of urban middle school students toward leisure reading. Young Adult Library Services, 39-45.

Kalaman, S., Keklik, C. \& Özkul, R. (2019). Türkiye'nin Akdeniz Bölgesi'ndeki ortaokul öğrencilerinin internete yönelik epistemolojik inançları. Ege Üniversitesi İletişim Fakültesi Yeni Düşünceler Hakemli E-Dergisi, (12), 33-43. Retrieved from https://dergipark.org.tr/tr/pub/euifydhed/issue/51506/636883. (Erişim Tarihi: 20.04.2020).

Kanadlı, S. \& Akbaş A. (2015). Fen bilgisi öğretmen adaylarının epistemolojik inançları, öğrenme yaklaşımları ve LYS puanları arasındaki ilişkiler. Mersin Üniversitesi Eğitim Fakültesi Dergisi. 11(1), 116-131. Retrieved from https://dergipark.org.tr/tr/pub/mersinefd/issue/17396/181893. (Erişim Tarihi: 20.04.2020).

Karasar, N. (2007). Bilimsel araştırma yöntemi (17. Bask1). Ankara: Nobel Yayınları.

Katranc1, M. (2015). İlkokul dördüncü sınıf öğrencilerinin kitap okuma motivasyonlarının incelenmesi. Ana Dili Eğitimi Dergisi, 3(2), 49-62. DOI: 10.16916/aded.41165.

Kılıç Çakmak, E., Karaoğlan Yılmaz, F. G. \& Yılmaz, R. (2015). İnternete yönelik epistemolojik inanç ölçeğinin uyarlama çalışması. Eğitim Teknolojisi Kuram ve Uygulama Dergisi. 5(1), 53-71. DOI: 10.17943/etku.47870.

Koç, S. \& Memduhoğlu, H. B. (2017). Öğretmen adaylarının epistemolojik inançları: Bir karma yöntem çalışma. Elektronik Sosyal Bilimler Dergisi. 16(60),119-134. DOI: 10.17755/esosder.289655.

Koçak, B., Çermik, F., Polat, S. \& Şahin, N. (2016). Öğretmen adaylarının kitap okuma tutumlarının çeşitli değişkenler açısından incelenmesi. Uluslararası Türkçe Edebiyat Kültür Eğitim Dergisi, 5(1), 395-411. DOI: 10.7884/teke.588.

Koçak, Ö., Yıldırım, Ö., Kurşun, E. \& Yıldırım, G. (2016). Investigating the status of tablet computers and e-books use of open education faculty students: A Case Study. International Journal of Distance Education Technologies (IJDET), 14(2), 49-63. DOI: 10.4018 / IJDET.2016040104.

Kolaç, E. (2007). Sınıf öğretmeni adaylarının okuyucu profilleri. Anadolu Üniversitesi VI. Ulusal Sinı Öğretmenliği Ĕ̆itimi Sempozyumu, 27-29 Nisan 2007, 209-214. 
Korkmaz, İ. (2007). Üniversite birinci sinıfta okuyan öğrencilerin lise döneminde kitap okuma durumlarının incelenmesi. Eurasian Journal of Educational Research, 27, 127-138.

Kurnaz, H. \& Yıldız, N. (2015). Ortaokul öğrencilerinin okuma motivasyonlarının çeşitli değişkenlere göre değerlendirilmesi. Türkiye Sosyal Araştırmalar Dergisi, 19(3), 53-70. https://www.researchgate.net/publication/341251130 (Erişim tarihi: 16.05.2020).

Kuşdemir, Y. \& Bulut, P. (2018). The relationship between elementary school students' reading comprehension and reading motivation. Journal of Education and Training Studies, 6(12), 97-110. DOI:10.11114/jets.v6i12.3595.

Mazman, S. G. \& Usluel, Y. K. (2009). The usage of social networks in educational context. International Journal of Behavioral, Cognitive, Educational and Psychological Sciences, 1(4). 224-228. https://www.researchgate.net/publication/282701525 (Erişim tarihi:16.05.2020).

Oksal, A., Şenşekerci, E. \& Bilgin A. (2006). Merkezi epistemolojik inançlar ölçeğinin geliştirilmesi: geçerlik ve güvenirlik. Ĕgitim Fakültesi Dergisi. 19(2), 371-381. Retrieved from https://dergipark.org.tr/tr/pub/uefad/issue/16684/173375.

OKUYAY (2019). Türkiye okuma kültürü araştırması. Erişim adresi file://C:/Users/COMU/Downloads/okuma-kulturu-arastirmasi\%20(1).pdf Erişim Tarihi: 16.05.2020.

Otrar, M. \& Argın, F. S. (2014). Öğrencilerin sosyal medyaya ilişkin tutumlarının kullanım alışkanlıkları bağlamında incelenmesi. Ĕ̈itim ve Öğretim Araştırmaları Dergisi, 3(3). http://www.jret.org/FileUpload/ks281142/File/01.otrar.pdf (Erişim tarihi:16.05.2020).

Özel, A. (2018). Sosyal bilgiler ögretmen adaylarının medya okuryazarlı̆̆ algılarının incelenmesi. (Yayımlanmamış doktora tezi.). Kütahya Dumlupınar Üniversitesi, Eğitim Bilimleri Enstitüsü, Kütahya.

Sadioğlu, Ö. \& Bilgin, A. (2008). İlköğretim öğrencilerinin eleştirel okuma becerileri ile cinsiyet ve anne-baba eğitim durumu arasındaki ilişki. Elementary Education Online, 7(3), 814822. http://ilkogretim-online.org.tr/index.php/io/article/view/1782/1618 (Erişim adresi:17.05.2020).

Sezgin, M., Bakır Ayğar, B. \& Gündoğdu, M. (2019). Üniversite öğrencilerinde üstbilişsel farkındalık ve epistemolojik inancın incelenmesi. Mersin Üniversitesi Eğitim Fakültesi Dergisi, 15(1), 276-289. DOI: 10.17860/mersinefd.331325.

Stutz, F., Schaffner, E. \& Schiefele, U. (2016). Relations among reading motivation, reading amount, and reading comprehension in the early elementary grades. Learning and Individual Differences, 45, 101-113. DOI: https://doi.org/10.1016/j.lindif.2015.11.022.

Şahin, N. (2019). Türkçe öğretmeni adaylarının okuma motivasyonlarının çeşitli değişkenler açısından incelenmesi. OPUS-Uluslararası Toplum Araştırmaları Dergisi, 13(19), 393423. DOI: 10.26466 /opus.588759.

Şencan H. (2005). Sosyal ve davranışsal ölçümlerde güvenilirlik ve geçerlilik (1. Baskı). Ankara: Seçkin Yayıncilık.

Smaragdi, U. J. \& Jonsson, A. (2006). Book reading in leisure time: Longterm changes in young peoples' book reading habits. Scandinavian Journal of Educational Research, 50(5), 519540 .

Tektaş, N. (2014). Üniversite Öğrencilerinin sosyal ağları kullanımlarına yönelik bir araştırma. Tarih Okulu Dergisi, 7(XVII), 851-870. DOI:http://dx.doi.org/10.14225/Joh474.

Terzi, A. R. (2005). Üniversite öğrencilerinin bilimsel epistemolojik inançları üzerine bir araştırma. Sosyal Bilimler Dergisi, 7(2), 298-311. https://sbd.aku.edu.tr/VII2/Terzi.pdf (Erişim tarihi:15.05.2020). 
Türk Dil Kurumu. (2011). Türkçe sözlük. (11. bask1). Ankara: Türk Dil Kurumu Yayınları.

Ülper, H. \& Çeliktürk, Z. (2013). Öğretmen adaylarının okuma motivasyonlarının değerlendirilmesi: Mehmet Akif Ersoy Üniversitesi örneği. Adlyaman Üniversitesi Sosyal Bilimler Enstitüsü Dergisi (Türkçenin Eğitimi Öğretimi Özel Sayısı), 6(11), 1033-1057. DOI: 10.14520/adyusbd.451.

Ural, A. \& Kılıç, İ. (2006). Bilimsel araştırma süreci ve SPSS ile veri analizi. Ankara: Detay Yayıncilik.

Vural, Z. B. A. \& Bat M. (2010). Yeni bir iletişim ortamı olarak sosyal medya: Ege üniversitesi iletişim fakültesine yönelik bir araştırma. Journal of Yaşar University, 20(5), 3348-3382. https://www.researchgate.net/publication/338331180. (Erişim tarihi:15.05.2020).

Yenice, N., Alpak Tunç, G. \& Yavaşoğlu N. (2018). Ortaöğretim öğrencilerinin bilimsel epistemolojik inançlarının incelenmesi. Mehmet Akif Ersoy Üniversitesi Ĕ̈itim Fakültesi Dergisi, (45), 132-152. DOI: 10.21764/maeuefd.334536.

Yıldız, N. \& Keskin, H. (2016). Ergenlik dönemindeki öğrencilerin dijital ve matbu okumaya karş1 tutumlarının çeşitli değişkenlere göre değerlendirilmesi. Mersin Üniversitesi Eğitim Fakültesi Dergisi, 12(1), 344-361. DOI: http://dx.doi.org/10.17860/efd.82485.

Yıldız, M. (2013). İlköğretim 3, 4 ve 5. sınıf öğrencilerinin okuma motivasyonlarının incelenmesi. Eğitim ve Bilim, 38(168), 260-271. http://egitimvebilim.ted.org.tr/index.php/EB/article/view/1574 (Erişim tarihi:15.05.2020).

Yıldız, M., Yıldırım, K., Ateş, S. \& Çetinkaya, Ç. (2013). Yetişkin okuma motivasyonu ölçeğinin Türkçe uyarlaması. Elektronik Sosyal Bilimler Dergisi, 12(44), 348-359.

Yılmaz, M. (2009). Üniversite öğrencilerinin okuma alışkanlığı üzerine bir inceleme (Cumhuriyet üniversitesi eğitim fakültesi Türkçe eğitimi bölümü örneği). Çukurova Üniversitesi Eğitim Fakültesi Dergisi, 3(37), 144-167. https://arastirmax.com/en/publication/cukurovauniversitesi-egitim-fakultesi-dergisi/3/37/universite-ogrencilerinin-okuma-aliskanligiuzerine-bir-inceleme-cumhuriyet-universitesi-egitim-fakultesi-turkce (Erişim tarihi: 16.05.2020).

Yılmaz, B. (2012). Okuma alışkanlığının okul başarısına etkisi: Ankara Keçiören Atapark İlköğretim Okulu öğrencileri üzerine bir araștırma. Ö. Külcü, T. Cakmak, N. Özel, (Editörler), Prof. Dr. K. Gülbün Baydur'a Armağan kitabı içinde (210-218). Ankara: Özyurt Matbaacılik. http://bby.hacettepe.edu.tr/yayinlar/Y\%C4\%B1lmaz.pdf (Erişim tarihi:16.05.2020).

Yılmaz, B., Köse, E. \& Korkut, Ş. (2009). Hacettepe üniversitesi ve Bilkent üniversitesi öğrencilerinin okuma alışkanlıkları üzerine bir araştırma. Türk Kütüphaneciliği, 23(1), 2251. Retrieved from https://dergipark.org.tr/tr/pub/tk/issue/48930/624184. (Erişim Tarihi: 20.04.2020).

Yılmaz, C. \& Çalışkan, M. (2017). Yatılı ortaokul öğrencilerinin okuma motivasyonlarının incelenmesi. Electronic Turkish Studies, 12(33), 573-588. DOI: 10.7827/TurkishStudies.12541. 